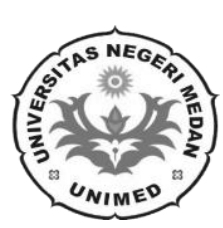

\title{
PENGARUH IMPLEMENTASI SISTEM ENTERPRISE RESOURCE PLANNING (ERP) TERHADAP KUALITAS INFORMASI AKUNTANSI
}

\author{
Dian Maulana Akbar, Khairunnisa Harahap \\ Universitas Negeri Medan \\ dian.maulana.akbar@wbi.ac.id,nisaharahap@yahoo.com
}

\begin{abstract}
Abstrak : Penelitian ini bertujuan untuk mengkaji bagaimana kualitas informasi akuntansi perusahaan manufaktur dapat dipengaruhi oleh implementasi sistem Enterprise Resource Planning. Variabel dependen yang digunakan dalam penelitian ini adalah relevansi informasi akuntansi (LAGT) yang diukur dengan jarak antara waktu berakhirnya tahun fiskal dengan tanggal pelaporan di Bursa Eek Indonesia, variabel independen yang digunakan dalam penelitian ini adalah sistem Enterprise Resource Planning (ERP) yang diukur menggunakan dummy dimana 1 untuk perusahaan yang menggunakan ERP dan 0 untuk perusahaan yang belum menggunakan ERP, dalam penelitian ini juga terdapat variabel kontrol yaitu konsentrasi kepemilikan, komisaris independen, leverage, profitabilitas, opini audit, dan ukuran perusahaan. Sampel diambil dengan menggunakan purposive sampling dengan jumlah sample yaitu sebanyak 52 perusahaan yang sesuai kriteria dengan 27 perusahaan pengguna sistem ERP dan 25 perusahaan yang belum menggunakan ERP. Data yang dikumpulkan adalah data sekunder dengan metode dokumentasi. Penelitian ini menggunakan analisis regresi berganda dan uji asumsi klasik untuk analisis data yang meliputi uji normalitas, uji multikolinieritas, uji heteroskedastisitas dan uji autokorelasi. Uji f, uji t dan uji koefisien determinasi digunakan dalam menguji hipotesis penelitian. Hasil dalam penelitian ini sistem enterprise resource planning mempengaruhi relevansi informasi akuntansi perusahaan manufaktur. Dua variabel kontrol yaitu leverage dan profitabilitas berpengaruh terhadap relevansi informasi akuntansi. Sementara variabel kontrol konsentrasi kepemilikan, komisaris independen opini audit dan ukuran perusahaan tidak berpengaruh signifikan terhadap relevansi informasi akuntansi. Kesimpulan dalam penelitian ini adalah implemantasi sistem enterprise resource planning berpengaruh signifikan terhadap relevansi informasi akuntansi. Variabel kontrol leverage dan profitabilitas berpengaruh signifikan terhadap relevansi informasi akuntansi. Namun untuk variabel kontrol konsentrasi kepemilikan, komisaris independen opini audit dan ukuran perusahaan tidak berpengaruh signifikan terhadap relevansi informasi akuntansi.
\end{abstract}

Kata Kunci : Enterprise Resource Planning, Kualitas Informasi Akuntansi 


\section{Pendahuluan}

Saat ini lingkungan bisnis mengalami kemajuan yang sangat signifikan salah satu halnya dalam kemampuan berkompetitif. Dalam mempertahankan keunggulan kompetitifnya, suatu perusahaan tidak terlepas dengan menggunakan teknologi informasi, yang digunakan untuk kelancaran penyaluran data pada setiap bagian sehingga dapat menghasilkan informasi yang akan digunakan oleh manajemen untuk dapat memenuhi kebutuhan masyarakat dalam memperoleh kecepatan dan keakuratan pelayanan yang dibutuhkan.

Salah satu penentu keberhasilan manajemen perusahaan adalah tersedianya data dan informasi perusahaan yang akurat untuk dipakai sebagai dasar perencanaan, pemantauan, dan evaluasi. Pihak manajemen perusahaan membutuhkan informasi yang dapat mendukung mereka dalam pengambilan keputusan salah satunya mengenai informasi akuntansi. Sistem informasi akuntansi sangat berperan dalam pengendalain dan pengamanan harta perusahaan. Sistem informasi akuntansi mengumpulkan data akuntansi dan mengolahnya menjadi informasi berupa laporan keuangan dan laporan lainnya. Laporan-laporan tersebut menggambarkan informasi tentang segala aktivitas perusahaan yang digunakan sebagai dasar pengambilan keputusan oleh manajemen perusahaan maupun pihak lainnya diluar perusahaan.

Sistem Informasi Akuntansi yang terstruktur dan berfungsi dengan baik akan membantu perusahaan dengan data-data keuangan perusahaan. Jika sistem Informasi Akuntansi yang digunakan oleh perusahaan tidak dapat bekerja dengan baik maka kualitas dari informasi akuntansi yang dihasilkan juga akan menurun dan menghambat kinerja dari perusahaan. Sesuai dengan pendapat Nuryanti \& Suprantiningrum (2016) sistem informasi akuntansi memiliki banyak peran penting dalam perusahaan, seperti memperbaiki kualitas dan mengurangi biaya dalam menghasilkan barang dan jasa, memperbaiki pengambilan keputusan, dan menciptakan keunggulan kompetitif. Menurut DeLone \& McLean (1992) mengemukakan kesuksesan dari sistem informasi tergantung pada kualitas informasi yang di hasilkan.

Kualitas informasi merupakan kualitas output yang berupa informasi yang dihasilkan oleh sistem informasi yang digunakan. Suatu infomasi akuntansi yang berkualitas memiliki empat dimensi yaitu keakuratan data, dapat diartikan bahwa informasi akuntansi tersebut benar-benar mencerminkan situasi dan kondisi yang ada. Relevan, dapat diartikan bahwa informasi akuntansi yang dihasilkan benar-benar sesuai dengan kebutuhan. Tepat waktu, dapat diartikan bahwa informasi akuntansi tersedia pada saat informasi tersebut diperlukan. Lengkap, dapat diartikan bahwa informasi akuntansi yang dihasilkan tersebut telah selengkap yang diinginkan dan dibutuhkan.

Menurut Susanto (2017:10) Semakin baik kualitas informasi yang dimiliki oleh suatu perusahaan maka akan semakin baik pulalah komunikasi yang terjadi didalam organisasi tersebut. Dengan meningkatnya kualitas komunikasi di dalam suatu perusahaan maka semakin baik pula integritas organisasi tersebut. Dengan demikian dapat disimpulkan bahwa informasi yang berkualitas tersebut sangat berpengaruh pada jalannya aktivitas perusahaan untuk mencai tujuan perusahaan.

Salah satu dimensi kualitas informasi akuntansi yang penting dari sistem informasi yaitu ketepatan waktu dalam penyajian informasi. Ketepatan waktu merupakan salah satu syarat agar suatu informasi dapat bermanfaat bagi pengguna. Salah satu informasi yang di butuhkan pengguna terutama investor adalah laporan keuangan. Penyajian laporan keuangan merupakan sarana bagi perusahaan untuk menyampaikan berbagai informasi dan pengukuran secara ekonomi mengenai sumber daya yang dimiliki serta kinerjanya kepada berbagai pihak yang memiliki kepentingan atas informasi tersebut. Hal ini menunjukkan bahwa ketepatan waktu dalam penyajian laporan keuangan ke publik sangat dibutuhkan dan oleh karena itu tiap-tiap perusahaan diharapkan tidak melakukan penundaan dalam penyajian laporan keuangan. Ketepatan waktu juga dapat mempengaruhi relevansi informasi keuangan yang disajikan. Informasi pada laporan keuangan dikatakan relevan apabila informasi tersebut disampaikan secara tepat waktu dan mempunyai manfaat bagi pemakai informasi sedangkan informasi keuangan dikatakan tidak relevan apabila terjadi penundaan dalam penyampaian laporan keuangan. 
Masalah kualitas output informasi selama ini masih belum memuaskan pengguna yang di akibatkan oleh beberapa faktor, yaitu seperti begitu banyaknya data yang ada pada perusahaan sehingga memakan waktu yang lama untuk mengorganisirnya, penerapan teknologi informasi yang belum terpenuhi dan kemampuan yang kurang untuk menjalankan teknologi baru. Hal ini mengakibatkan jalannya sistem terganggu dan kurang optimal sehingga mengakibatkan seringkali terjadinya keterlambatan dalam penyajian laporan keuangan. Perusahaan sangat membutuhkan sistem informasi yang terintegrasi dengan baik agar data yang disajikan adalah data real time. Selain menampilkan data real time, syarat lain dari sistem informasi yang diperlukan saat ini adalah dapat menampilkan data tersebut dengan mudah, cepat akurat serta dapat di pertanggung jawabkan.

Keterlambatan penyajian laporan keuangan di Bursa Efek Indonesia masih sering terjadi. Hal ini dibuktikan dengan adanya surat pengumuman yang dikeluarkan oleh Bursa Efek Indonesia pada tahun 2019, bahwasannya ada 10 perusahaan yang belum menyajikan laporan keuangan per 31 Desember 2018. Tetntunya hal ini mengakibatkan pihak perusahaan dikenakan denda dan laporan keuangannya mengalami penurunan kualitas yang berdampak pada kebijakan investasi dari para investor.

Saat ini sistem infomasi telah mengalami kemajuan yang sangat signifikan. Dimana salah satunya sistem informasi telah terintegrasi kedalam komputer yang membuat para manajemen memilih untuk menggunakannya demi mempermudah pekerjaan dan meningkatkan kinerja perusahaan. Salah satu sistem informasi yang banyak digunakan manajemen saat ini yaitu sistem Enterprise Resource Planning (ERP). ERP mempunyai tujuan untuk merangkum proses bisnis yang ada sehingga menjadi satu kolaborasi yang efisien dan efektif dengan mengintegrasikan kegiatan di setiap area fungsional peusahan, antar deartemen, maupun antar lokasi yang berbeda. Dengan sistem yang terintegrasi tersebut perbedaan proses antar fungsi, departemen dan lokasi yang berbeda akan kecil ataupun tidak ada.

ERP adalah perangkat lunak yang merupakan solusi untuk bisnis skala besar. Sistem ERP terdiri dari modul untuk dukungan perangkat lunak, seperti pemasaran dan penjualan, layanan lapangan, desain dan pengembangan produk, produksi dan pengendalian persediaan, pengadaan, distribusi, manajemen fasilitas industri, desain proses dan pengembangan, manufaktur, kualitas, sumber daya manusia, keuangan dan akuntansi, dan layanan informasi. Kemampuan untuk mengintegrasikan proses bisnis di suatu perusahaan ini yang kemudian menjadi daya tarik tersendiri bagi pihak manajemen untuk menerapkan ERP .Senada dengan Rukmiyati \& Budiartha (2016) Konsep ERP adalah sebuah sistem yang mengintegrasikan proses bisnis setiap divisi dalam manajemen perusahaan secara transparansi dan memiliki akuntabilitas yang cukup tinggi. Inilah yang selanjutnya melatar belakangi banyak perusahaan di dunia, termasuk di Indonesia beramai-ramai untuk menerapkan ERP di perusahaannya.

Meski penerapan sistem Enterprise Resource Planning (ERP) telah banyak dilakukan oleh perusahaan-perusahaan didunia termasuk di Indonesia. Beberapa perusahaan yang telah mengimplementasikan sistem Enterprise Resource Planning (ERP) adalah PT. Indocement Tunggal Prakarsa Tbk, PT. Kalbe Farma Tbk, PT. Semen Batu Raja Persero Tbk, dan perusahan-perusahaan manuaktur lainnya. Hasil yang diperoleh dari penerapan sistem ERP berbedabeda di setiap perusahaan tergantung bagaimana perusahaan tersebut dapat mengoptimalkan kinerja sistem tersebut. Keberhasilan atau kegagalan dalam menerapkan ERP diukur dari manfaat yang diterima perusahaan yaitu berupa peningkatan kinerja pada perusahaan. Dengan menerapkan sistem Enterprise Resource Planning (ERP), perusahaan mengalami beberapa perubahan terutama dalam informasi akuntansi. Data yang sebelumnya memerlukan waktu yang cukup lama ketika akan di olah untuk laporan keuangan, sekarang dapat di kumpulkan dengan cepat karena sudah terintegrasinya setiap informasi pada seluruh fungsi pada perusahaan, hal ini pastinya juga mempercepat penyajian laporan keuanga perusahaan. Selain itu penerapan sistem ERP juga mengakibatkan keakuratan data lebih terjamin, mempermudah kinerja manajemen, meningkatkan efiesiensi dan efektivitas organisasi melalui alokasi sumber daya perusahaan secara optimal, serta meningkatkan kualitas informasi akuntansi untuk pengambilan keputusan. Sesuai dengan pendapat Galy \& Sauceda, (2014) bahwa, Enterprise Resource Planning memiliki satu hal penting di dalam perusahaan yaitu ERP dapat memberikan informasi secara akurat dan real time kepada perusahaan. 
Implementasi sistem ERP mengakibatkan perubahaan yang cukup signifikan dalam bidang informasi akuntansi. Perubahan tersebut terjadi pada proses penyiapan. Pada mulanya proses pelaporan berdasarkan proses manual, yang mana laporan diolah menunggu semua data berbagai divisi telah diberikan. Sekarang laporan dapat dibuat dengan cepat karena semua data sudah terecord dalam sistem ERP. Wibisono (2013) menambahkan bahwa, pembuatan informasi menjadi lebih efektif sehingga mampu meningkatkan kemampuan manajer dalam menganalisa infromasi akuntansi tersebut. Implementasi ERP mampu menyediakan informasi keuangan dalam kondisi apapun setiap dibutuhkan. Kemampuan sistem terintegrasi ini mengurangi hambatan antara fungsi organisasi membuat manajer memiliki kemampuan untuk mengakses informasi akuntansi yang belum pernah dilakukan sebelumnya.

\section{Studi Literatur}

\section{Teori Keagenan}

Teori yang mendasari kualitas informasi akuntansi pada penelitian ini adalah teori keagenan. Teori keagenan menurut Jensen \& Meckling (1976) adalah teori yang menghubungkan antara agen (pengelola perusahaan) dengan prinsipal (pemilik perusahaan) yang terikat alam kontrak. Hubungan antara agen dengan prinsipal yaitu agen sebagai pihak yang menjalankan dan mengambil keputusan sedangkan prinsipal adalah pihak yang mengevaluasi kinerja dari agen. Jadi, agen sebagai pengelola perusahan memiliki kewajiban untuk melaporkan hasil kinerjanya kepada prinsial. Teori agensi mengasumsikan bahwa individu bertindak memaksimalkan kepentingan diri sendiri, maka dengan disasimetri informasi yang dimilikinya akan mendorong agent untuk melakukan hal-hal yang diinginkannya dan menyembunyikan beberapa informasi yang tidak diketahui prinsipal.

Kecenderungan dalam menyembunyikan informasi berdampak terhadap keterlambatan pelaporan laporan keuangan. Jika dalam pelaporan informasi akuntansi tersebut mengalami penundaan yang disebabkan karena faktor kepentingan agen sehingga menggangu prinsipal dalam pengambilan keputusan maka kualitas dari informasi akuntansi tersebut akan menurun atau tidak relevan lagi. Menurut Givoly \& Palmon (1982) laporan keuangan yang mengalami keterlambatan pelaporan merupakan berita buruk (bad news) bagi perusahaan. Diharapkan dengan adanya sebuah sistem yang terorganisasi dengan baik dapat memperkecil kemungkinan negatif dan dapat mengontrol perilaku agen.

\section{Kualitas Informasi Akuntansi}

Pengertian Kualitas Informasi Akuntansi Informasi akuntansi yang diinformasikan dalam bentuk laporan keuangan perusahaan merupakan media komunikasi antara kegiatan usaha perusahaan dengan pihak-pihak yang berkepentingan atas posisi keuangan dan perkembangan usaha perusahaan. Informasi akuntansi memiliki kegunaan yang sangat bergantung pada pemakainya. Agar informasi akuntansi yang disajikan dalam bentuk laporan keuangan dapat digunakan sebagai dasar pembuatan keputusan, maka bagian akuntansi dituntut untuk dapat menyajikan informasi akuntansi yang berkualitas. Menurut Rahayu (2018), kualitas informasi akuntansi adalah informasi akuntansi yang disajikan secara akurat dan tepat waktu yang memiliki kualitas andal bebas dari pengertian yang menyesatkan yang dapat memberikan manfaat kepada pemakai informasi tersebut. Senada dengan Kuntum (2019) Kualitas informasi akuntansi adalah informasi akuntansi yang disajikan secara akurat dan tepat waktu memiliki kualitas yang dapat diandalkan bebas dari gagasan yang menyesatkan yang dapat memberikan manfaat kepada pengguna informasi. Informasi berkualitas baik dapat mendorong kesuksesan perusahaan di masa depan. Dari beberapa pengertian di atas dapat disimpulkan bahwa kualitas informasi adalah informasi yang tersedia saat di butuhkan atau tepat waktu, berisi keadaan sebenarnya dan informasi yang diberikan lengkap. Ciri-ciri Informasi Akuntansi yang Berkualitas, Menurut James O'Brien dalam bukunya Management Information System, ada 3 dimensi mutu informasi yaitu dimensi waktu informasi (time dimension), dimensi konten informasi (content dimension), dan dimensi bentuk informasi (form dimension). Karakteristik dalam dimensi ini adalah pilihan analis sistem informasi. Menurut James O’Brien (Azizah, Mirfani \& Surya, 2016) tidak semua harus masuk tapi disesuaikan dengan kebutuhan.

A. Time Dimension (dimensi waktu informasi)

a) Currency alias Up to date. Informasi yang disampaikan tepat waktu. Buat sistem informasi 
yang menyajikan informasi basi. Tidak bisa digunakan apalagi untuk mengambil keputusan. Informasi yang tersaji cepat akan memuaskan pengguna dan mendukung pengambilan keputusan.

b) Timeliness alias tersedia kapan saja user membutuhkan. Artinya informasi tersedia kapan pun user menginginkannya. Pagi, siang, sore, bahkan tengah malam. Mungkin yang saat ini lagi dikembangkan adalah aplikasi sistem informasi via handphone (mobile application).

c) Frequency yang berarti informasi tersedia dalam periode waktun tertentu. Hampir sama dengan kategori up to date.

B. Content Dimension (dimensi konten informasi)

a) Accuracy. Jelas bahwa informasi yang tersedia akurat, bebas dari kesalahan sehingga tidak menjerumuskan user dan berakibat salah dalam mengambil keputusan.

b) Relevance. Nah, informasi yang tersedia sesuai dengan business core atau kebutuhan user. Jangan sampai informasi yang tersedia tidak dibutuhkan user.

c) Conciseness. Dimaksudkan bahwa informasi yang disajikan diperlukan oleh user. Misal informasi prakiran cuaca, user membutuhkan suhu sekarang berapa, akan hujan atau tidak, berapa kecepatan angin, layak tidak untuk berlayar.

C. Form Dimension (dimensi bentuk informasi), bentuk informasi adalah cara bagaimana informasi tersebut sampai ke user. Media apa yang sebaiknya digunakan. Apakah sistem informasi stand alone atau yang online. Bisa diakses melalui apa, televisi, radio, komputer, layar lebar (seperti di jalan-jalan), atau melalui ponsel. Pilihan-pilihan ini dikembalikan lagi pada kebutuhan sistem berdasarkan hasil analisis permasalahan saat ini.

Sedangkan dalam Statement of Financial Accounting Concepts (SFAC) No.2 Qualitatif of Accounting Information dikutip dari Rahayu (2018) yang menjelaskan karakterisik yang membuat informasi akuntansi berkualitas yaitu relevan. Agar relevan, informasi akuntansi harus mampu membuat perbedaan dalam sebuah keputusan. Dan informasi yang relevan mencakup:

- Nilai Prediksi, informasi yang diihasilkan akan membantu pemakai membuat prediksi tentang hasil akhir dari kejadian masa lalu, masa kini, dan masa depan.

- Nilai Umpan Balik, yaitu informasi yang relevan juga membantu pemakai menjustifikasi atau mengoreksi kesalahan-kesalahan masa lalu.

- Tepat Waktu, agar relevan informasi juga harus tersedia kepada pengambil keputusan sebelum informasi tersebut kehilangan kapasitas untuk mempengaruhi keputusan yang diambil.

Menurut Alvin (2018) Ketepatan waktu adalah faktor yang sangat penting pada relevansi informasi akuntansi. Karena jika dalam penyajian informasi keuangan mengalami penundaan maka akan mempengaruhi pengambilan keputusan dari pihak yang berkepentingan. Seperti pendapat Kwong (2010) bahwa informasi harus segera disampaikan kepada pengguna informasi sebelum informasi tersebut kehilangan nilai atau manfaat untuk mempengaruhi pengambilan keputusan.

\section{Enterprise Resource Planning (ERP)}

Pengertian Enterprise Resource Planning (ERP)

Menurut Galy \& Sauceda (2014) Enterprise resource planning (ERP) adalah salah satu teknologi informasi yang banyak diimplementasikan perusahaan di dunia karena ERP dapat memberikan informasi secara akurat dan real time kepada perusahaan. Menurut Susanto (2017:18) Enterprise Resource Planning merupakan suatu konsep yang didukung oleh software seperti Oracle dan SAP yang dirancang untuk mengintegrasikan seluruh data dan software aplikasi SIA yang dibangun perusahaan. Menurut Hall (2011;34) mengemukakan pengertian Enterprise Resource Planning (ERP) adalah model sistem informasi yang memungkinkan suatu organisasi untuk mengotomatisasi dan mengintegrasikan proses bisnis utamanya. Sedangkan menurut Indrayani \& Maulidahniar (2017) Enterprise Resource Planning (ERP) adalah suatu sistem informasi berbasis komputer (software, frame work) yang digunakan oleh perusahaaan manufaktur dan perusahaan jasa untuk mengontrol, mengelola sumber daya internal dan eksternal berwujud termasuk aset, perencanaan distribusi barang, proses produksi barang, pemesanan barang, sumber daya keuangan, dan sumber daya manusia dalam menghasilkan suatu sistem informasi.

Menurut beberapa pendapat para ahli di atas, maka bisa disimpulkan sistem Enterprise Resource Planning adalah struktur sistem informasi berupa sofware yang dapat mengintegrasikan fungsi pemasaran, fungsi produksi, fungsi logistik, fungsi keuangan, fungsi sumber daya, fungsi produksi, 
dan fungsi lainnya.

Modul-Modul Enterprise Resource Planning (ERP)

Sistem Enterprise Resource Planning (ERP) memiliki cakupan fungsi yang sangat luas, di dalam fungsi-fungsi tersebut terdapat komponen-komponen yang biasa disebut dengan istilah modul. software ERP biasanya terbagi atas modul utama yakni Operasi serta modul pendukung yakni Finansial dan Akuntansi serta sumber daya manusia. Menurut Irfani (2015) dijelaskan modul-modul ERP adalah sebagai berikut :

- Modul Operasi adalah : Modul yang berhubungan dengan pengontrolan produksi.

- Modul Finansial dan Akuntansi adalah : Modul yang berhubungan dengan masalah keuangan dan akuntansi.

- Modul Sumber Daya Manusia adalah : Modul yang berhubungan dengan sumber daya manusia.

Pengaruh Sistem Enterprise Resource Planning terhadap Relevansi Informasi Akuntansi Sistem ERP memberikan informasi akuntansi yang lebih tepat waktu dan efektif bagi pengguna. Ketepatan waktu adalah bagian terpenting pada relevansi informasi akuntansi yang disebabkan apabila infformasi keuangan terlambat dalam penyajiannya maka akan membuat informasi tersebut mengalami penurunan nilai dan menghambat keputusan para pihak yang berkepentingan. Jadi, diharapkan standar dan sistem ERP yang terintegrasi dapat memproses transaksi secara efisien dan mempersingkat keterlambatan pelaporan informasi keuangan (Brazel \& Dang, 2008). Selain itu, sistem ERP mengumpulkan informasi keuangan dan juga informasi non-keuangan. Dengan demikian, ia bisa memberikan informasi kekayaan dan informasi menyeluruh perusahaan untuk pengambilan keputusan. Dalam lingkungan ERP, pengguna juga dapat menyesuaikan informasi berdasarkan permintaan spesifik mereka. Jadi, permintaan informasi spesifik pengguna dapat dipenuhi, dan pada akhirnya relevansi informasi akuntansi ditingkatkan (Ou et al., 2018).

Gambar 2.1 Kerangka Berfikir

Variabel Independen

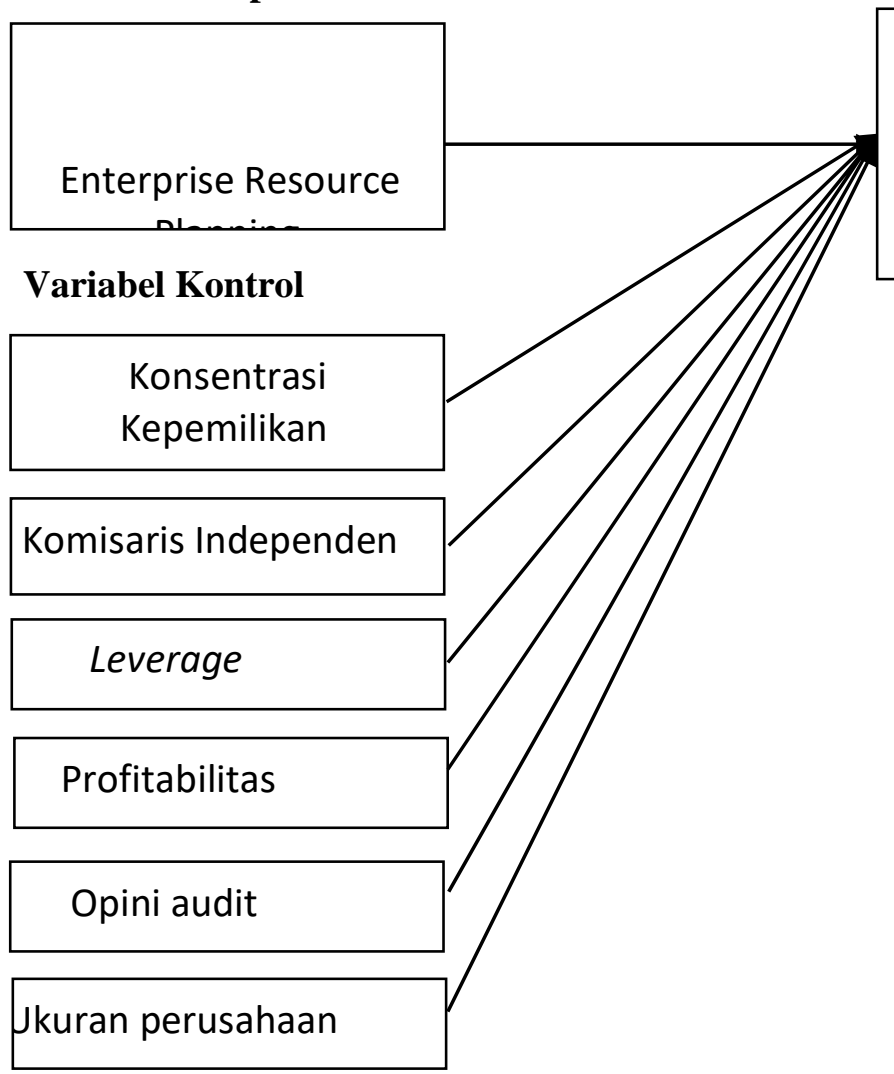

Variabel Dependen

Relevansi Informasi Akuntansi

\section{Hipotesis Penelitian :}

H1 : Implementasi ERP berpengaruh terhadap relevansi informasi akuntansi 


\section{Metodologi Penelitian}

\subsection{Lokasi dan Waktu Penelitian}

Penelitian dilakukan di Bursa Efek Indonesia (Indonesia Stock Exchange/IDX) melalui situs www.idx.co.id yang di khususkan pada perusahaan-perusahaan yang termasuk dalam jenis perusahaan manufaktur. Penelitian ini dilakukan pada bulan April 2020 sampai dengan selesai. Adapun data yang digunakan dalam penelitian ini adalah data sekunder.

\subsection{Populasi}

Populasi adalah wilayah generalisasi yang terdiri atas objek/subjek yang mempunyai kualitas dan karak teristik yangditetapkan oleh untuk dipelajari kemudian menarik kesimpulan (Sugiyono, 2017 : 80). Populasi dalam penelitian ini adalah perusahaan-perusahaan yang termasuk dalam jenis perusahaan manufaktur yang terdaftar di Bursa Efek Indonesia (Indonesia Stock Exchange/IDX) tahun 2016 hingga tahun 2018. Alasan penulis memilih perusahaan manufaktur sebagai populasi karena ruang lingkup perusahaan yang bergerak dibidang manufaktur luas dan permasalahan yang terjadi lebih kompleks sehingga diharapkan mampu menggambarkan keadaan perusahaan Indonesia.

\subsection{Sampel}

Sampel adalah bagian dari jumlah dan karakteristik yang dimiliki oleh populasi tersebut (Sugiyono, 2017 ; 80). Teknik Pengambilan sampel pada penelitian ini dilakukan dengan menggunakan metode purposive sampling untuk mendapatkan sample yang tepat bagi penelitian ini. Sampel yang dipilih harus memenuhi kriteria sebagai berikut :

1. Perusahaan manufaktur yang terdaftar di Bursa Efek Indonesia (BEI) periode 2016- 2018.

2. Perusahaan manufaktur yang menerbitkan laporan keuangan secara lengkap pada periode 2016-2018.

3. Perusahaan Manufaktur yang menggunakan mata uang rupiah selama periode $2016-2018$.

4. Perusahaan manufaktur yang tidak mengalami kerugian selama periode 2016-2018.

\subsection{Variabel Penelitian}

Dalam penelitian ini, penulis menggunkan beberapa variabel yaitu sebagai berikut:

1. Variabel Dependen (terikat) yaitu relevansi informasi akuntansi.

2. Variabel Independen (bebas) yaitu enterprise resource planning.

3. Variabel Kontrol yaitu konsentrasi kepemilikan, komisaris independen, leverage, profitabilitas, opini audit, ukuran perusahaan.

\subsection{Defenisi Operasional}

Definisi operasional adalah suatu definisi yang diberikan kepada suatu variabel dengan cara memberikan arti atau menspesifikasikan kegiatan ataupun memberikan suatu operasional yang diberikan untuk mengukur variabel tersebut. Definisi Operasional dari masing-masing variabel akan dijelaskan sebagai berikut:

\section{Variabel Dependen}

\section{Relevansi Informasi Akuntansi}

Relevansi memiliki arti bahwa informasi akuntansi harus memiliki nilai prediktif, nilai umpan balik, dan ketepatan waktu. Ketepatan waktu adalah satu atribut penting dari relevansi. Hanya informasi yang tepat waktu yang relevan. Pengurangan waktu siklus pelaporan berarti perusahaan lebih mungkin memberikan informasi keuangan kepada pengguna eksternal dengan cara yang lebih tepat waktu. Berdasarkan literatur sebelumnya menurut Ou et al (2018), ketepatan waktu 
menggunakan jeda waktu pelaporan keuangan dengan menggunakan selisih antara tanggal pengumuman laporan yang terdapat di Bursa Efek Indonesia (Indonesia Stock Exchange/IDX) dan berakhirnya tahun fiskal.

2. Variabel Independen

\section{Enterprise Resource Planning}

Dalam penelitian ini mengukur apakah ERP diimplementasikan dalam suatu perusahaan mengikuti metode penelitian sebelumnya, yaitu variabel dummy dengan nilai 1 untuk perusahaan yang mengimplementasi ERP dan 0 untuk perusahaan yang tidak mengimplementasikan ERP. Informasi perusahaan menggunakan sistem ERP dilihat pada laporan keuangan dan website perusahaan.

\section{Variabel Kontrol}

Variabel kontrol adalah variabel yang dikendalikan atau dibuat konstan sehingga pengaruh variabel independen terhadap dependen tidak dipengaruhi oleh faktor luar yang tidak diteliti (Sugiyono ,2017;41). Dalam penelitian ini variabel kontrol yang digunakan yaitu sebagi berikut :

\section{A. Konsentrasi Kepemilikan}

Konsentrasi kepemilikan mencerminkan adanya kepemilikan saham dimana terdapat distribusi kekuasaan dan pengaruh di antara pemegang saham dalam kegiatan operasional perusahaan. Menurut Shleifer \& Vishny (Rohmatullaily, 2019), mengukur konsentrasi kepemilikan dapat dilakukan dengan melihat tingkat kepemilikan oleh suatu pihak lebih dari 51\%. Hal tersebut memperlihatkan terdapatnya hak kontrol oleh pemegang saham pengendali. Penelitian ini menghitung konsentrasi kepemilikan menggunakan variable dummy, dimana $1=$ perusahaan terkonsentrasi dan $0=$ perusahaan tidak terkonsentrasi.

\section{B. Komisaris Independen}

Untuk mengetahui proporsi komisaris independen dapat dihitung dengan rumus di bawah ini :

$$
\text { komisaris independen }=\frac{\text { jumlah komisaris independen }}{\text { jumlah seluruh dewan komisaris }} \times 100 \%
$$

\section{Leverage}

Rasio leverage diproksikan dengan rasio hutang terhadap aktiva. Perusahaan dengan tingkat laverage yang tinggi memiliki dorongan yang besar untuk mengungkapkan banyak informasi kepada kreditor, dapat dihitung dengan rumus dibawah ini :

$$
\mathrm{DER}=\frac{\text { total hutang }}{\text { total aktiva }} 100 \%
$$

\section{Profitabilitas}

Rasio Profitabilitas diukur menggunakan Return on Asset (ROA). Semakin tinggi tingkat ROA suatu perusahaan menandakan kinerja keuangan yang baik. Perusahaan dengan tingkat profitabilitas yang tinggi meningkatkan pengaruh dalam keputusan investor dan memiliki stakeholder yang lebih menarik, sehingga ada kecenderungan lebih tinggi untuk pengungkapan tepat waktu.

$$
\mathrm{ROA}=\frac{\text { laba bersih }}{\text { total aset }} 100 \%
$$




\section{E. Opini Audit}

Opini audit merupakan hal yang ingin diketahui informasinya oleh pengguna laporan keuangan. Opini audit diukur menggunakan variabel dummy dengan ketentuan bahwa perusahaan yang menerima opini audit wajar tanpa pengecualian (WTP) dari auditor selama tahun berjalan diberi nilai 1 sedangkan perusahaan yang menerima opini lain selama tahun berjalan seperti wajar tanpa pengecualian dengan paragraf penjelasan (WTPDPP), wajar dengan pengecualian (WDP), tidak wajar (TW), dan tidak memberikan pendapat (TMP) diberi nilai 0.

\section{F. Ukuran Perusahaan}

Ukuran perusahaan yang semakin besar akan memiliki sistem informasi manajemen yang lengkap dan kompleks, maka perusahaan tersebut harus dapat menyediakan informasi yang lebih baik, serta mengguakan teknologi sistem yang terorganisir seperti ERP. Penelitian ini menggunakan total asset (size yaitu log natural) sebagai ukurannya.

$$
\text { Ukuran Perusahaan }(\text { SIZE })=\text { LN }(\text { Total Asset })
$$

\subsection{Jenis Data}

Data yang digunakan adalah data sekunder. Penggunaan data sekunder didasarkan karena perusahaan yang diteliti adalah perusahaan manufaktur di Bursa Efek Indonesia (BEI). Pemilihan perusahaan yang terdaftar di Bursa Efek Indonesia karena perusahaan pada umumnya mempunyai kewajiban untuk mengeluarkan laporan tahunan untuk kebutuhan pihak luar perusahaan, sehingga data dapat diperoleh oleh peneliti. Data yang digunakan adalah data laporan tahunan perusahaan manufaktur yang listing (terdaftar) di Bursa Efek Indonesia (BEI) pada tahun 2016-2018.

\subsection{Sumber Data}

Sumber data berupa laporan keuangan tahun yang diperoleh melalui bursa efek indonesia yang dipublikasi melalui website www.idx.co.id dan website perusahaan.

\subsection{Teknik Pengumpulan Data}

Teknik pengumpulan data dalam penelitian ini adalah metode dokumentasi yaitu mengumpulkan data sekunder berupa laporan keuangan perusahaan yang telah diaudit dan dipublikasikan selama periode pengamatan dengan mengunduhnya dari situs $\underline{w w w . i d x . c o . i d}$

\subsection{Teknik Analisis Data}

Teknik pengumpulan data dalam penelitian ini adalah metode dokumentasi yaitu mengumpulkan data sekunder berupa laporan keuangan perusahaan yang telah diaudit dan dipublikasikan selama periode pengamatan dengan mengunduhnya dari situs www.idx.co.id

\section{A. Statistik Deskriptif}

Statistik Deskriptif berhubungan dengan pengumpulan data dan peringkasan data, penyamplingan serta penyajian hasil peringkasan tersebut. Analisis statistik deskriptif digunakan untuk memberikan deskripsi atas variabel-variabel penelitian secara statistik. Statistik deskriptif yang digunakan adalah nilai rata-rata (mean), maksimum, minimum,dan standar deviasi.

\section{B. Uji Asumsi Klasik}

\section{Uji Normalitas}

Sebelum data dilakukan uji regresi, terlebih dahulu data dilakukan uji normalitas. Uji normalitas bertujuan menguji apakah dalam model regresi mempunyai residu dengan distribusi normal (Ghozali, 2016). Pada penelitian ini, uji normalitas berfungsi untuk menentukan alat uji statistik apa yang digunakan. Dalam penelitian ini, uji normalitas dilakukan dengan One-Sample Kolmogrov Smirnov 
Test. Uji Kolmogorov Smirnov merupakan uji beda data yang diuji normalitasnya dengan data normal baku. Apabila data yang diuji ternyata normal maka akan digunakan statsistic parametic dimana hipotesis diuji dengan uji regresi.

a. Angka signifikansi (Asymp. Sig) $>0,05$, maka data berdistribusi normal.

b. Angka signifikansi (Asymp. Sig) $<0,05$, maka data tidak berdistribusi normal.

\section{Uji Multikolinieritas}

Uji Multikoliniearitas berguna untuk menguji apakah model regresi ditemukan adanya korelasi antar variabel independen. Cara mengetahui ada tidaknya penyimpangan uji multikolinieritas adalah dengan melihat nilai Tolerance dan VIF (Variance Inflation Factor). Masing-masing variabel independen, jika nilai Tolerance $>0.10$ dan nilai VIF $<10$ maka tidak terdapat gejala multikolinearitas. Model regresi yang baik seharusnya tidak terjadi multikolinearitas (Ghozali, 2016).

\section{Uji Heteroskedastisitas}

Uji heteroskedastisitas bertujuan untuk menguji dalam model regresi terjadi ketidaksamaan varians dari residual satu pengamatan ke pengamatan yang lain. Cara untuk mengetahui terjadi heteroskedastisitas atau tidak yaitu dengan melihat Grafik Plot antara nilai prediksi variabel dependen yaitu SRESID dengan residualnya ZPRED. Tidak terjadi heteroskedastisitas yaitu apabila tidak ada pola yang jelas, serta titik-titik menyebar di atas dan di bawah angka 0 pada sumbu Y. Suatu model regresi seharusnya tidak terjadi heteroskedastisitas atau jika varian dari residual suatu pengamatan terhadap pengamatan lainnya adalah tetap (Ghozali, 2016).

\section{Uji Autokorelasi}

Uji autokorelasi bertujuan untuk menguji dalam model regresi linear ada atau tidak korelasi antara kesalahan pengganggu pada periode $t$ dengan kesalahan pengganggu pada periode $\mathrm{t}-1$ atau periode sebelumnya. Uji autokorelasi pada penelitian ini menggunakan uji Durbin Watson h. Menurut Ghozali (2016), autokorelasi muncul karena observasi yang berurutan sepanjang waktu berkaitan satu sama lainnya. Permasalahan ini muncul karena residual tidak bebas dari satu observasi ke observasi lainnya.

\subsection{Model Persamaan Regresi Berganda}

Model regresi yang dikembangkan untuk menguji hipotesis-hipotesis yang telah dirumuskan dalam penelitian ini. Model regresi digunakan untuk menguji pengaruh variabel independen terhadap variabel dependen. Variabel relevansi informasi akuntansi dengan ketepatan waktu sebagai indikator dengan variabel kontrol konsentrasi kepemilikan, komisaris independen, leverage, profitabilitas, opini audit, dan ukuran perusahaan memiliki persamaan regresi sebagai berikut:

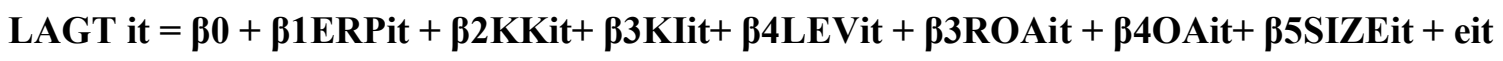

LAGT $=$ Selisih antara tanggal pengumuman laporan keuangan di BEI dan berakhirnya tahun fiskal.

ERPit $=$ Enterprise Resource Planning

KKit $=$ Konsentrasi Kepemilikan KIit $=$ Komisaris Independen LEVit $=$ Leverage

ROAit $=$ Profitabilitas perusahaan dengan return on asset OAit $=$ Opini audit

SIZEit $=$ Ukuran Perusahaan

Eit $\quad=$ error term, secara normal terdistribusi antara rata-rata 0 .

\subsection{Pengujian Hipotesis}

Analisis Regresi adalah salah satu metode yang sangat popular dalam mencari hubungan antara variabel atau lebih. Variabel-variabel yang dikomputasi selanjutnya dikelompokkan menjadi variabel 
dependen yang biasanya dinotasikan dengan huruf $\mathrm{Y}$ dan variabel independen yang biasanya dinotasikan dengan huruf $\mathrm{X}$. Adapun pengujian yang dilakukan dalam analisis regresi linier berganda dalam penelitian ini adalah:

\section{A. Uji Statistik Simultan (Uji-F)}

Uji Statistik F pada dasarnya menunjukkan apakah semua variabel independen atau bebas yang dimasukkan dalam model mempunyai pengaruh secara bersama-sama terhadap variabel dependen (Ghozali, 2013). Menurut Ghozali (2013) untuk menguji hipotesis ini digunakan statistik F dengan kriteria pengambilan keputusan sebagai berikut:

1. Jika nilai signifikansi $F$ yang diperoleh nilainya lebih kecil dari nilai signifikansi yang digunakan yaitu sebesar 5\% maka dapat disimpulkan bahwa semua variabel independen berpengaruh terhadap variabel dependen.

2. Jika nilai signifikansi $\mathrm{F}$ yang diperoleh nilainya lebih besar dari nilai signifikansi yang digunakan yaitu sebesar 5\% maka dapat disimpulkan bahwa semua variabel independen tidak berpengaruh terhadap variabel dependen.

\section{B. Uji Statistik Parsial (Uji-t)}

Uji Statistik t pada dasarnya menunjukkan seberapa jauh pengaruh satu variabel independen secara individual dalam menerangkan variasi variabel dependen (Ghozali, 2016). Menurut Ghozali (2016) cara pengambilan keputusan dengan menggunakan uji t yaitu sebagai berikut:

1. Apabila nilai $\mathrm{t}$ menurut perhitungan lebih tinggi dibandingkan dengan nilai signifikansi sebesar 5\% maka variabel independen secara individu mempengaruhi variabel dependen.

2. Apabila nilai t menurut perhitungan lebih rendah dibandingkan dengan nilai signifikansi sebesar 5\% maka variabel independen secara individu tidak mempengaruhi variabel dependen.

\section{Uji Koefisien determinasi (R2)}

Koefisien Determinasi (R2) pada intinya mengukur seberapa jauh kemampuan model dalam menerangkan variasi variabel dependen (Ghozali, 2011:97). Nilai koefisien determinasi adalah nol dan satu. Nilai yang kecil berarti kemampuan variabel-variabel independen dalam menjelaskan variasi variabel dependen amat terbatas. Nilai mendekati satu berarti variabel- variabel independen memberikan hampir semua informasi yang dibutuhkan untuk memprediksi variasi variabel dependen (Ghozali, 2011:97)

\section{Hasil Penelitian}

\section{Hasil Penelitian}

\section{Gambaran Umum Sampel}

Data yang digunakan dalam penelitian ini adalah data sekunder yang berasal dari laporan keuangan yang diunduh dari Indonesia Stock Exchange (www.idx.co.id). Populasi dalam penelitian ini adalah seluruh perusahaan manufaktur yang terdaftar di Bursa Efek Indonesia pada periode 20162019 yang berjumlah 162 perusahaan. Penentuan sampel ditentukan dengan metode purposive sampling berdasarkan kriteria-kriteria yang telah ditentukan. Dari 162 populasi ditemukan bahwa terdapat 52 perusahaan yang memenuhi kriteria pengambilan sampel dengan periode penelitian 3 tahun yaitu 2016-2018. Sehingga jumlah observasi dalam penelitian ini sebanyak 156 data observasi dari seluruh populasi. Kriteria dalam pengambilan sampel adalah sebagai berikut: 
Tabel 4. 1 Pemilihan Sampel

\begin{tabular}{|c|l|c|}
\hline No. & \multicolumn{1}{|c|}{ Kriteria } & Jumlah \\
\hline 1. & $\begin{array}{c}\text { Perusahaan manufaktur yang terdaftar di Bursa Efek Indonesia periode } \\
2016-2018\end{array}$ & 162 \\
\hline 3. & $\begin{array}{l}\text { Perusahaan manufaktur yang tidak menerbitkan laporan keuangan untuk } \\
\text { periode yang berakhir pada tanggal 31 } \\
\text { Desember 2016 sampai dengan 31 Desember 2018 }\end{array}$ & $(43)$ \\
\hline 4. & $\begin{array}{l}\text { Laporan keuangan perusahaan manufaktur tidak menggunakan } \\
\text { mata uang Rupiah }\end{array}$ & $(30)$ \\
\hline 5. & $\begin{array}{l}\text { Perusahaan yang mengalami kerugian pada periode 2016-2018 } \\
\text { Total }\end{array}$ \\
\hline
\end{tabular}

Sumber:Data sekunder yang diolah, 2020 (Lampiran A.1)

Berikut ini nama-nama perusahaan yang menjadi sampel dalam penelitian, sebagai berikut:

Tabel 4. 2 Nama-Nama Perusahaan yang Menjadi Sampel Penelitian

\begin{tabular}{|c|c|c|}
\hline No. & Kode saham & Nama Perusahaan \\
\hline 1. & AGGI & PT Aneka Gas Industri, Tbk \\
\hline 2. & AKPI & PT Argha Karya Prima Industry, Tbk \\
\hline 3. & ALKA & PT Alakasa Industrindo, Tbk \\
\hline 4. & AMFG & PT Asahimas Flat Glass, Tbk \\
\hline 5. & ARNA & PT Arwana Citramulia, Tbk \\
\hline 6. & AUTO & PT Astra Otoparts, Tbk \\
\hline 7. & BATA & PT Sepatu Bata, Tbk \\
\hline 8. & BUDI & PT Budi Starch \& Sweetener, Tbk \\
\hline 9. & CEKA & PT Wilmar Cahaya Indonesia, Tbk \\
\hline 10. & CINT & PT Chitose Internasional, Tbk \\
\hline 11. & CPIN & PT Charoen Pokphand Indonesia, Tbk \\
\hline 12. & DVLA & PT Darya Varia Laboratoria, Tbk \\
\hline 13. & EKAD & PT Eka Dharma Internasional, Tbk \\
\hline 14. & FASW & PT Fajar Surya Wisesa, Tbk \\
\hline 15. & GGRM & PT Gudang Garam, Tbk \\
\hline 16. & ICBP & PT Indofood Sukses Makmur, Tbk \\
\hline 17. & IGAR & PT Champion Pacific Indonesia, Tbk \\
\hline 18. & IMPC & PT Impact Pratama Industri, Tbk \\
\hline 19. & INAI & PT Indal Alumunium Industry, Tbk \\
\hline 20. & INDF & PT Indofood Sukses Makmur, Tbk \\
\hline 21. & INTP & PT Indocement Tunggal Prakarsa, Tbk \\
\hline 21. & ISSP & PT Steel Pipe Industry of Indonesia, Tbk \\
\hline 23. & JECC & PT Jembo Cable Company, Tbk \\
\hline 24. & JPFA & PT Japfa Comfeed Indonesia, Tbk \\
\hline 25. & KAEF & PT Kimia Farma, Tbk \\
\hline 26. & KBLI & PT KMI Wire \& Cable, Tbk \\
\hline 27. & KDSI & PT Kedawung Setia Industrial, Tbk \\
\hline 28. & KINO & PT Kino Indonesia, Tbk \\
\hline 29. & KLBF & PT Kalbe Farma, Tbk \\
\hline 30. & LION & PT Lion Metal Works, Tbk \\
\hline 31. & LMSH & PT Lionmesh Prima, Tbk \\
\hline
\end{tabular}




\begin{tabular}{|l|l|l|}
\hline 32. & MLIA & PT Mulia Industrindo, Tbk \\
\hline 33. & MYOR & PT Mayora Indah, Tbk \\
\hline 34. & PICO & PT Pelangi Indah Canindo, Tbk \\
\hline 35. & RICY & PT Ricky Putra Globalindo, Tbk \\
\hline 36. & ROTI & PT Nippon Indosari Corpindo, Tbk \\
\hline 37. & SCCO & PT Supreme Cable Manufacturing \& Commerce, Tbk \\
\hline 38. & SIDO & PT Industri Jamu dan Farmasi Sido Muncul, Tbk \\
\hline 39. & SKBM & PT Sekar Bumi, Tbk \\
\hline 40. & SKLT & PT Sekar Laut, Tbk \\
\hline 41. & SMBR & PT Semen Baturaja, Tbk \\
\hline 42. & SMGR & PT Semen Indonesia, Tbk \\
\hline 43. & SPMA & PT Suparma, Tbk \\
\hline 44. & STAR & PT Buana Artha Anugerah, Tbk \\
\hline 45. & TCID & PT Mandom Indonesia, Tbk \\
\hline 46. & TOTO & PT Surya Toto Indonesia, Tbk \\
\hline 47. & TRIS & PT Trisula International, Tbk \\
\hline 48. & TRST & PT Trias Sentosa, Tbk \\
\hline 49. & TSPC & PT Tempo Scan Pacific, Tbk \\
\hline 50. & ULTJ & PT Ultra Jaya Milk Industry \& Trading Company, Tbk \\
\hline 51. & VOKS & PT Voksel Electric, Tbk \\
\hline 52. & WSBP & PT Waskita Beton Precast, Tbk \\
\hline & & Sumb : WWW.idx.coid \\
\hline
\end{tabular}

Sumber : www.idx.co.id

Pada tabel 4.2 dapat diketahui bahwa perusahaan yang telah memenuhi kriteria sampel ada 52 perusahaan dengan tahun pengamatan selama 3 tahun dari perusahaan Manufaktur yang terdaftar maka jumlah sampel sebanyak 156 data.

\section{Analisis Statistik Deskriptif}

Deskriptif data digunakan untuk memberikan gambaran mengenai data yang diperoleh dari hasil penelitian. Deskriptif data ini meliputi nilai minimum, nilai maximum, mean, standar deviasi, dan variance. Hasil Perhitungan statistik deskriptif dari variabel independent yaitu enterprise resource planning, variabel kontrol yaitu konsentrasi kepemilikan, komisaris independen, leverage, profitabilitas, opini audit, ukuran perusahaan, dan variabel dependen yaitu relevansi informasi akuntansi ditunjukkan pada tabel 4.3.

Tabel 4. 3 Hasil Uji Analisis Statistik Deskriptif

Descriptive Statistics

\begin{tabular}{|l|r|r|r|r|r|}
\hline & N & Minimum & Maximum & Mean & \multicolumn{1}{|c|}{$\begin{array}{c}\text { Std. } \\
\text { Deviation }\end{array}$} \\
\hline Erp & 156 & 0 & 1 &, 52 &, 501 \\
Kk & 156 & 0 & 1 &, 90 &, 304 \\
Ki & 156 &, 20 &, 67 &, 4072 &, 08996 \\
Lv & 156 &, 08 &, 84 &, 4152 &, 17735 \\
Roa & 156 &, 00 &, 20 &, 0640 &, 04666 \\
Oa & 156 & 0 & 1 &, 9679 &, 17670 \\
Size & 156 & 18,73 & 25,29 & 21,9099 & 1,43749 \\
Lagt & 156 & 33 & 140 & 98,01 & 23,134 \\
Valid N (listwise) & 156 & & & & \\
\hline
\end{tabular}

Sumber: Hasil Pengujian Data, 2020 
Berdasarkan tabel 4.3 dapat di deskripsikan sebagai berikut:

1. Variabel dependen dalam penelitian ini adalah Relevansi Informasi Akuntansi. Hasil statistik deskriptif untuk variabel ini menunjukkan nilai tertinggi (maximum) sebesar 140 dan nilai terendah (minimum) sebesar 33. Nilai rata-rata (mean) dari variabel dependen ini adalah 98,01. Nilai standar deviasi (standar deviation) adalah 23,134.

2. Variabel independen dalam penelitian ini adalah Enterprise Resource Planning (Erp). Hasil statistik deskriptif untuk Enterprise Resource Planning menunjukkan nilai maximum sebesar 1 dan nilai minimum sebesar 0. Nilai mean dari variabel Enterprise Resource Planning adalah 0,52 dan nilai standar deviation adalah 0,501 .

3. Variabel kontrol pertama dalam penelitian ini adalah Konsentrasi Kepemilikan (Kk). Hasil statistik deskriptif untuk Konsentrasi Kepemilikan menunjukkan nilai maximum sebesar 1 dan nilai minimum sebesar 0. Nilai mean dari Konsentrasi Kepemilikan adalah 0,90 dan nilai standar deviation 3,04.

4. Variabel kontrol kedua dalam penelitian ini adalah Komisaris Independen (Ki). Hasil statistik deskriptif untuk Komisaris Independen menunjukkan nilai maximum sebesar 0,67 dan nilai minimum sebesar 0,20. Nilai mean dari variabel Komisaris Independen adalah 0,4072 dan standar deviation adalah 0,08996 .

5. Variabel kontrol ketiga dalam penelitian ini adalah Leverage (Lv). Hasil statistik deskriptif untuk variabel leverage menunjukkan nilai maximum sebesar 0,84 dan nilai minimum sebesar 0,08. Nilai mean dari variabel laverage adalah 0,4152 dan nilai standar deviation adalah 0,17735 .

6. Variabel kontrol keempat dalam penelitian ini adalah Profitabilitas (Roa). Hasil statistik deskriptif untuk profitabilitas menunjukkan nilai maximum sebesar 0,20 dan nilai minimum sebesar 0,00 . Nilai mean dari variabel profitabilitas adalah 0,0640 dan nilai standar deviation adalah 0,04666 .

7. Variabel kontrol kelima dalam penelitian ini adalah Opini Audit (Oa). Hasil statistik deskriptif untuk opini audit menunjukkan nilai maximum sebesar 1 dan nilai minimum sebesar 0 . Nilai mean dari variabel likuiditas adalah 0,9679 dan nilai standar deviation adalah 0,17670 .

8. Variabel kontrol keenam dalam penelitian ini adalah Ukuran Perusahaan (size). Hasil statistik deskriptif untuk ukuran perusahaan menunjukkan nilai maximum sebesar 25,29 dan nilai minimum sebesar 18,25. Nilai mean dari variabel ukuran perusahaan adalah 21,9099 dan nilai standar deviation adalah 1,43749.

Data perusahaan manufaktur yang menggunakan sistem ERP dapat dilihat pada tabel 4.4 berikut.

Tabel 4. 4 Data Perusahaan Pengguna Sistem ERP

\begin{tabular}{|l|l|l|}
\hline No. & Kode saham & \\
\hline 1. & AGGI & PT Aneka Gas Industri, Tbk \\
\hline 2. & ARNA & PT Arwana Citramulia, Tbk \\
\hline 3. & AUTO & PT Astra Otoparts, Tbk \\
\hline 4. & BATA & PT Sepatu Bata, Tbk \\
\hline 5. & CPIN & PT Charoen Pokphand Indonesia, Tbk \\
\hline 6. & FASW & PT Fajar Surya Wisesa, Tbk \\
\hline 7. & ICBP & PT Indofood Sukses Makmur, Tbk \\
\hline 8. & IGAR & PT Champion Pacific Indonesia, Tbk \\
\hline 9. & INDF & PT Indofood Sukses Makmur, Tbk \\
\hline 10. & INTP & PT Indocement Tunggal Prakarsa, Tbk \\
\hline 11. & ISSP & PT Steel Pipe Industry of Indonesia, Tbk \\
\hline 12. & JECC & PT Jembo Cable Company, Tbk \\
\hline 13. & JPFA & PT Japfa Comfeed Indonesia, Tbk \\
\hline 14. & KAEF & PT Kimia Farma, Tbk \\
\hline 15. & KINO & PT Kino Indonesia, Tbk \\
\hline 16. & KLBF & PT Kalbe Farma, Tbk \\
\hline & &
\end{tabular}




\begin{tabular}{|l|l|l|}
\hline 17. & MLIA & PT Mulia Industrindo, Tbk \\
\hline 18. & PICO & PT Pelangi Indah Canindo, Tbk \\
\hline 19. & SIDO & PT Industri Jamu dan Farmasi Sido Muncul, Tbk \\
\hline 20. & SKBM & PT Sekar Bumi, Tbk \\
\hline 21. & SMBR & PT Semen Baturaja, Tbk \\
\hline 22. & SMGR & PT Semen Indonesia, Tbk \\
\hline 23. & TOTO & PT Surya Toto Indonesia, Tbk \\
\hline 24. & TRIS & PT Trisula International, Tbk \\
\hline 25. & TSPC & PT Tempo Scan Pacific, Tbk \\
\hline 26. & ULTJ & PT Ultra Jaya Milk Industry \& Trading Company, Tbk \\
\hline 27. & WSBP & PT Waskita Beton Precast, Tbk \\
\hline & & Sumber: Hasil Pengujian Data, 2020 \\
\hline
\end{tabular}

Dari tabel data perusahaan pengguna sistem ERP dapat dilihat bahwa dari 52 perusahaan yang di jadikan sampel penelitian terdapat 27 perusahaan yang menggunakan sistem ERP. Informasi tersebut dapat dilihat dari laporan keuangan perusahaan dan juga pada website perusahaan terkait.

\section{Uji Asumsi Klasik}

Uji asumsi klasik dilakukan untuk mengetahui apakah model regresi benar-benar menunjukkan hubungan yang signifikan dan representatif. Model regresi tersebut harus memenuhi syarat asumsi klasik. Uji asumsi klasik yang digunakan dalam penelitian ini yaitu:

\section{Uji Normalitas Data}

Uji normalitas adalah untuk melihat apakah nilai residual terdistribusi normal atau tidak. Uji normalitas bertujuan untuk menguji apakah dalam model regresi, variabel pengganggu atau residual memiliki distribusi normal. Pada dasarnya normalitas dapat dideteksi dengan melihat titik-titik (penyebaran data) pada sumbu diagonal dari grafik atau dengan cara melihat histogram dari residualnya (Ghozali, 2016). Dasar pengambilan keputusan menurut Ghozali (2016) adalah :

a. Bila data menyebar pada sekitar garis diagonal dan mengikuti arah garis diagonal atau grafik histogramnya menunjukkan pola distribusi normal, maka model regresi tersebut memenuhi asumsi normalitas.

b. Bila data menyebar jauh dari diagonal atau tidak mengikuti arah garis diagonal atau grafik histogram tidak menunjukkan pola distribusi normal, maka model regresi tersebut tidak memenuhi asumsi normalitas.

Dalam penelitian ini uji normalitas data menggunakan Kolmogrov-Smirnov test. Dasar pengambilan keputusan untuk uji normalitas:

1. Signifikansi $>0,05\left(\mathrm{H}_{\mathrm{o}}\right.$ diterima: data normal $)$

2. Signifikansi $<0,05$ (Ha ditolak: data tidak normal)

Tabel 4.5 Hasil Uji Normalitas

One-Sample Kolmogorov-Smirnov Test

\begin{tabular}{|ll|r|}
\hline & & \multicolumn{2}{|c|}{$\begin{array}{l}\text { tandardized } \\
\text { Residual }\end{array}$} \\
\hline N & & 156 \\
Normal Parameters & \\
& Mean &, 0000000 \\
Most Extreme Differences & Std. Deviation & 20,41448974 \\
& Absolute &, 057 \\
& Positive &, 042 \\
Test Statistic & Negative &,- 057 \\
& &, 057
\end{tabular}




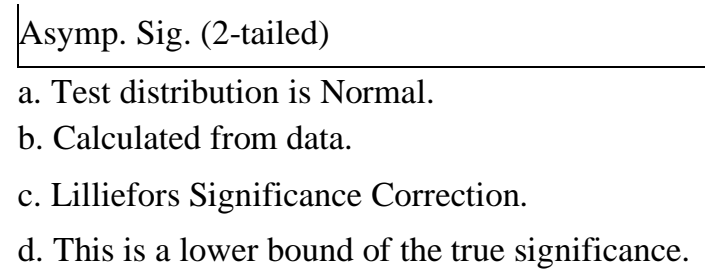

Sumber: Hasil Pengujian Data, 2020

Berdasarkan tabel di atas, diketahui bahwa nilai signifikansi sebesar 0,200 lebih besar dari 0,05. Sehingga dari tabel tersebut dapat disimpulkan bahwa data terdistribusi secara normal.

\section{Uji Multikolinieritas}

Uji Multikolinearitas bertujuan untuk menguji apakah model regresi ditemukan adanya korelasi antar variabel bebas/independen. Dalam penelitian ini, teknik yang digunakan adalah melihat nilai dari Variance Inflation Factor (VIF) dan nilai tolerance. Kedua ukuran ini menunjukkan setiap variabel independen mana saja yang dijelaskan oleh variabel independen lainnya.

Dalam mendeteksi ada atau tidaknya multikolinearitas dilakukan dengan melihat VIF (Variance Inflation Factor). VIF > 10 diduga mempunyai multikolinearitas yang tinggi dan VIF $<10$ tidak terdapat multikolinearitas. Tolerance > 0,10 tidak terdapat multikolinearitas (Ghozali, 2018:107). Berikut ini hasil output pengolahan data spss :

Tabel 4.6 Hasil Pengujian Multikolinearitas

\begin{tabular}{|c|c|c|c|}
\hline \multicolumn{4}{|c|}{ Coefficien $t^{\mathrm{a}}$} \\
\hline \multirow{2}{*}{\multicolumn{2}{|c|}{ Model }} & \multicolumn{2}{|c|}{ Collinearity Statistics } \\
\hline & & Tolerance & VIF \\
\hline \multirow{8}{*}{1} & (Constant) & & \\
\hline & ERPit & ,790 & 1,266 \\
\hline & Kkit & 931 & 1,074 \\
\hline & Kiit & ,978 & 1,022 \\
\hline & Lvit & ,759 & 1,318 \\
\hline & ROAit & ,713 & 1,402 \\
\hline & Oait & ,929 & 1,076 \\
\hline & SIZEit & 777 & 1,287 \\
\hline
\end{tabular}

a. Dependent Variable: LAGTit

Sumber: Hasil Pengujian Data, 2020

Berdasarkan tabel 4.6 di atas, dapat dideskripsikan bahwa :

1. Variabel ERPit memiliki nilai VIF sebesar 1,266 dan nilai tolerance sebesar 0,790.

2. Variabel KKSit memiliki nilai VIF sebesar 1,074 dan nilai tolerance sebesar 0,931.

3. Variabel KIit memiliki nilai VIF sebesar 1,022 dan nilai tolerance sebesar 0,978.

4. Variabel LVit memiliki nilai VIF sebesar 1,318 dan nilai tolerance sebesar 0,759.

5. Variabel ROAit memiliki nilai VIF sebesar 1,402 dan nilai tolerance sebesar 0,713.

6. Variabel OAit memiliki nilai VIF sebesar 1,076 dan nilai tolerance sebesar 0,929.

7. Variabel SIZEit memiliki nilai VIF sebesar 1,287 dan memiliki nilai tolerance sebesar 0,777.

Dari uraian diatas, hasil tersebut menunjukkan bahwa semua nilai VIF dari variabel independen memiliki nilai yang lebih kecil dari 10 dan nilai tolerance yang lebih besar dari 0,1 . Hasil pengujian model regresi untuk ukuran akrual tersebut menunjukkan tidak adanya gejala multikolinearitas dalam model regresi. Hal ini berarti bahwa semua variabel independen tersebut layak digunakan sebagai prediktor. 


\section{Uji Heteroskedastisitas}

Model regresi yang baik adalah yang homoskedastisitas atau tidak terjadi heteroskedatisitas (Ghozali, 2016). Metode yang digunakan untuk menguji heterokedastisitas adalah melihat gambar plot antara nilai prediksi variabel independen (ZPRED) dengan residual (SRESID). Apabila dalam grafik tersebut tidak terdapat pola tertentu yang teratur dan data tersebar secara acak diatas dan dibawah angka 0 pada sumbu Y, maka diidentifikasikan tidak terdap heterokedastisitas (Ghozali, 2016). Berikut adalah grafik plot antara nilai prediksi variabel terikat (dependen):

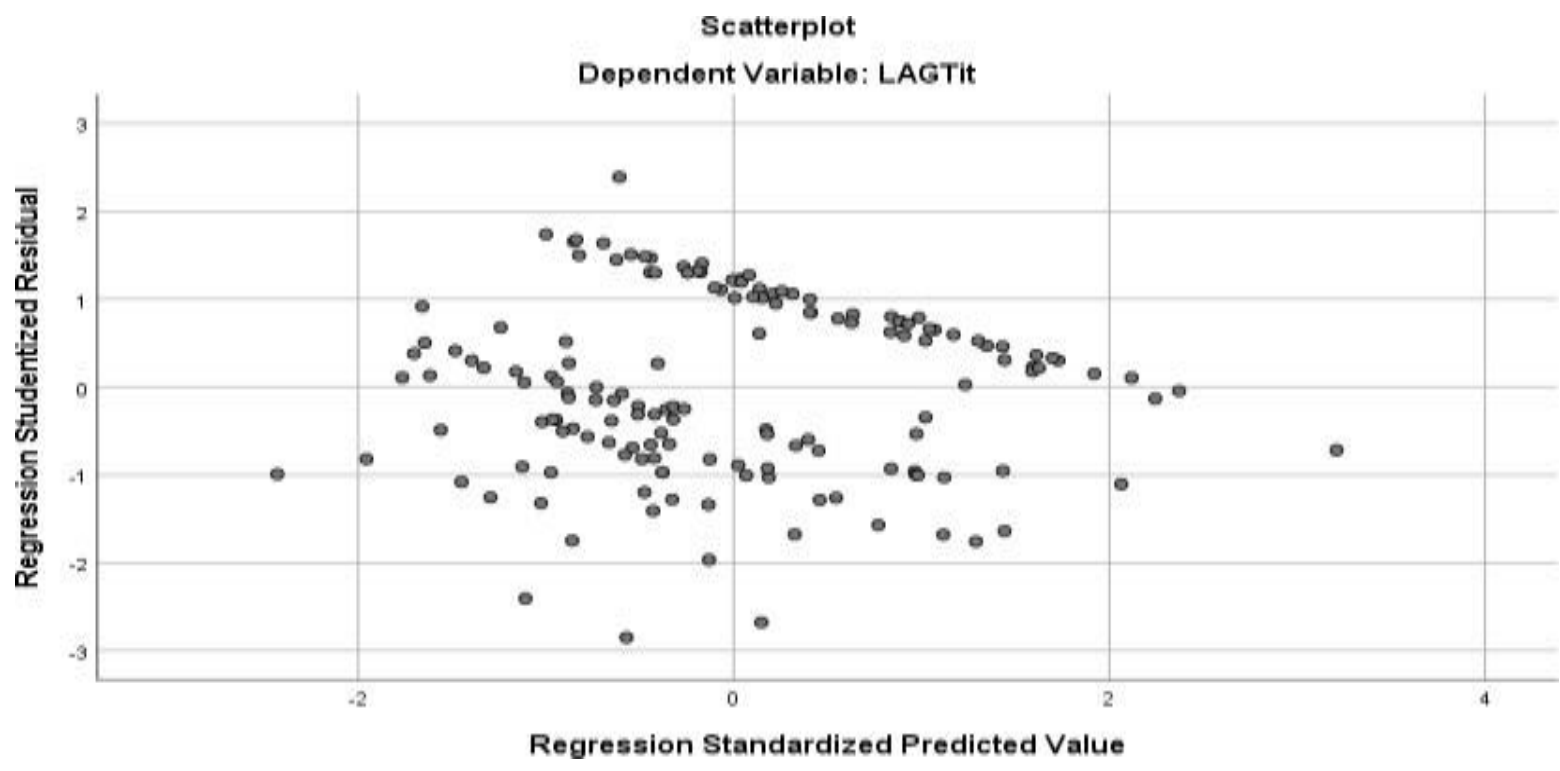

Sumber: Hasil Pengujian Data, 2020

Dari tampilan grafik scatterplot di atas terlihat bahwa titik-titik tersebar dengan acak diatas maupun dibawah angka 0 pada sumbu Y. Hal ini dapat disimpulkan bahwa tidak terjadi heteroskedastisitas pada model regresi. Peneliti juga menggunakan uji statistik yaitu Uji Glejser untuk meyakinkan bahwa tidak ada masalah heteroskedastisitas dalam model regresi. Berikut adalah hasil uji Gletser :

Tabel 4.7 Hasil Pengujian Heterokedastisitas

\begin{tabular}{|c|c|c|c|c|c|c|}
\hline \multicolumn{7}{|c|}{ Coefficients $^{\mathrm{a}}$} \\
\hline & & \multicolumn{2}{|c|}{$\begin{array}{l}\text { Unstandardized } \\
\text { Coefficients }\end{array}$} & \multirow{2}{*}{$\begin{array}{c}\begin{array}{c}\text { Standardized } \\
\text { Coefficients }\end{array} \\
\text { Beta }\end{array}$} & \multirow[b]{2}{*}{$\mathrm{T}$} & \multirow[b]{2}{*}{ Sig. } \\
\hline \multicolumn{2}{|c|}{ Model } & $\mathrm{B}$ & Std. Error & & & \\
\hline 1 & (Constant) & 3,032 & 15,844 & & , 191 & ,849 \\
\hline & ERPit & ,080 & 2,035 & ,004 & 039 & 969 \\
\hline & KKit & ,779 & 3,087 & 021 &, 252 & 801 \\
\hline & KIit & $-3,753$ & 10,188 &,- 030 &,- 368 & ,713 \\
\hline & Lvit &,- 343 & 5,868 &,- 005 &,- 059 & 953 \\
\hline & ROAit & $-2,617$ & 23,004 &,- 011 &,- 114 & 910 \\
\hline & OAit & 10,325 & 5,321 &, 163 & 1,940 & 054 \\
\hline & SIZEit &, 232 &, 715 & ,030 &, 324 & ,746 \\
\hline
\end{tabular}

a. Dependent Variable: abresid

Sumber: Hasil Pengujian Data, 2020 
Dari tabel hasil uji heterokedastisitas diatas menunjukkan nilai probibalitas signifikansi di atas 5\%, yaitu sebesar $97 \%$ untuk variabel ERPit, $80 \%$ untuk variabel KKit, $71 \%$ untuk variabel KIit, $95,3 \%$ untuk variabel LVit, $91 \%$ untuk variabel ROAit, 5,4\% untuk variabel Oait, dan $75 \%$ untuk variabel SIZEit. Jadi, dapat disimpulkan bahwa model regresi tidak mengandung adanya heterokedastisitas.

\section{Uji Autokorelasi}

Pada uji autokorelasi menggunakan Uji Durbin Watson $h$ karena variabel dependenya merupakan varibel lag. Lag artinya selisih antara sampel t dengan sampelt-1. Data regresi linear menggunakan data runtut waktu atau time-series. Hasil uji Durbin Watson h sebagai berikut:

Tabel 4.8 Hasil Pengujian Autokorelasi

\section{Model Summary}

\begin{tabular}{llrrrr} 
& & \multicolumn{3}{c}{ Std. Error of the } \\
Model & R & R Square & Adjusted R Square & Estimate & Durbin-Watson \\
\hline 1 &, $470^{\mathrm{a}}$ &, 221 &, 184 & 20,892 & 1,874
\end{tabular}

a. Predictors: (Constant), SIZEit, LVit, KIit, KKit, OAit, ERPit, ROAit

b. Dependent Variable: LAGTit

Sumber: Hasil Pengujian Data, 2020

Berdasarkan tabel 4.8 diatas nilai Durbin Watson sebesar 1,874,pembandingmenggunakan nilai signifikansi 5\% jumlah sampel 156 (n) dan jumlah varibel independen $7(\mathrm{k}=5)$, tabel durbin Watson akan didapat dL 1,530 dengan dU 1,722. Karena nilai dW 1,874 lebih besar dari nilai dU 1,722 dan 4dU 2,278 lebih besar dari dU maka tidak terdapat autokorelasi.

\section{Analisis Regresi Berganda}

Analisis regresi pada dasarnya adalah studi mengenai ketergantungan dependen (terikat) dengan satu atau lebih variabel independen (variabel penjelas/bebas), dengan tujuan untuk mengestimasi dan/atau memprediksi rata- rata populasi atau nilai variabel dependen berdasarkan nilai variabel independen diketahui (Gujarati, 2003) dalam (Ghozali, 2016). Berikut merupakan hasil uji regresi penelitian:

Tabel 4.9 Hasil Uji Regresi Berganda

\begin{tabular}{|c|c|c|c|c|c|c|}
\hline \multicolumn{7}{|c|}{ coeffisien $^{\mathbf{a}}$} \\
\hline & & \multicolumn{2}{|c|}{$\begin{array}{l}\text { Unstandardized } \\
\text { Coefficients }\end{array}$} & \multirow{2}{*}{$\begin{array}{c}\text { Standardized } \\
\text { Coefficients } \\
\text { Beta }\end{array}$} & \multirow[b]{2}{*}{$\mathrm{T}$} & \multirow[b]{2}{*}{ Sig. } \\
\hline \multicolumn{2}{|c|}{ Model } & $\mathrm{B}$ & Std. Error & & & \\
\hline \multirow[t]{8}{*}{1} & (Constant) & 156,761 & 29,329 & & 5,345 &, 000 \\
\hline & ERPit & $-12,520$ & 3,766 &,- 271 & $-3,324$ & ,001 \\
\hline & KKit & 7,242 & 5,714 & , 095 & 1,268 & ,207 \\
\hline & KIit & 8,253 & 18,859 & ,032 & ,438 & ,662 \\
\hline & Lvit & $-42,663$ & 10,862 &,- 327 & $-3,928$ & ,000 \\
\hline & ROAit & $-119,946$ & 42,583 & -,242 & $-2,817$ & ,006 \\
\hline & OAit & $-16,368$ & 9,851 &,- 125 & $-1,662$ & ,099 \\
\hline & SIZEit &,- 953 & 1,324 & \begin{tabular}{l|l|}
,- 059 \\
\end{tabular} &,- 719 & ,473 \\
\hline
\end{tabular}

a. Dependent Variable: LAGTit

Sumber: Hasil Pengujian Data, 2020 
Dari tabel analisis regresi linier berganda diatas, maka dapat diketahui rumus model persamaan regresi sebagai berikut :

LAGT $_{i t}=156,761-12,520 \mathrm{ERP}+7,242 \mathrm{KK}+8,253 \mathrm{KI}-42,663 \mathrm{LV}-119,946 \mathrm{ROA}-16,368 \mathrm{OA}$ 0,953SIZE $+\mathrm{e}_{\mathrm{it}}$

Adapun interpretasi regresi berganda di atas dapat dijelaskan sebagai berikut:

a) Konstanta sebesar 156,761 menyatakan apabila enterprise resource planning (ERPit), Konsentrasi Kepemilikan (KKit), Komisaris Independen (KIit), Leverage (LEVit), Profitabilitas (ROAit), Opini Audit (OAit) Ukuran Perusahaan (SIZEit), dianggap tidak ada maka nilai variable dependen atau Relevansi Informasi Keuangan (LAGTit) yang terjadi pada perusahaan adalah sebesar 156,761 .

b) Koefisien regresi enterprise resource planning (ERPit) sebesar $-12,520$, hal ini menyatakan bahwa penggunaan ERP pada perusahaan akan meningkatkan relevansi informasi akuntansi perusahaan dengan peningkatan ketepatan waktu pelaporan (LAGTit) sebesar 12,520.

c) Koefisien regresi Konsentrasi Kepemilikan (KKit) sebesar 7,242 menyatakan bahwa setiap Konsentrasi Kepemilikan (KKit) meningkat sebesar 1\% akan meningkatkan relevansi informasi akuntansi naik dengan peningkatan ketepatan waktu pelaporan (LAGTit) sebesar 7,242.

d) Koefisien regresi Komisaris Independen (KIit) sebesar 8,253 menyatakan bahwa setiap peningkatan Komisaris Independen (KIit) sebesar 1\% akan meningkatkan relevansi informasi akuntansi naik dengan peningkatan ketepatan waktu pelaporan (LAGTit) sebesar 8,253.

e) Koefisien regresi Leverage (LVit) sebesar $-42,663$ menyatakan bahwa setiap peningkatan Leverage (LVit) sebesar 1\% akan menurunkan relevansi informasi akuntansi dengan penurunan ketepatan waktu pelaporan (LAGTit) sebesar 42,663.

f) Koefisien regresi profitabilitas (ROAit) sebesar -119,946 menyatakan bahwa setiap peningkatan profitabilitas (ROAit) sebesar $1 \%$ akan menurunkan relevansi informasi akuntansi dengan penurunan ketepatan pelaporan (LAGTit) waktu sebesar 119,946.

g) Koefisien regresi Opini Audit (OAit) sebesar -16,368 menyatakan bahwa setiap peningkatan likuiditas LIQit sebesar 1\% akan menurunkan relevansi informasi akuntansi dengan penurunan ketepatan waktu pelaporan (LAGTit) sebesar 16,368.

h) Koefisien regresi Ukuran Perusahaan (Sizeit) sebesar -0,93 menyatakan bahwa setiap peningkatan Ukuran Perusahaan (Sizeit) sebesar 1\% akan menurunkan relevansi informasi akuntansi dengan penurunan ketepatan waktu pelaporan (LAGTit) sebesar 0,93.

Uji Hipotesis

Uji Signifikansi Simultan (Uji f)

Uji signifikansi simultan (Uji statistik f) digunakan untuk menguji besarnya pengaruh dari seluruh variabel penelitian secara bersama-sama atau simultan terhadap variabel dependen (Ghozali, 2016). Hasil pengujian uji signifikansi simultan (uji F) dalam penelitian ini ditunjukkan dalam tabel di bawah:

Tabel 4.10 Hasil Uji F

\begin{tabular}{|c|c|c|c|c|c|c|}
\hline \multicolumn{7}{|c|}{ ANOVA $^{a}$} \\
\hline Model & & $\begin{array}{l}\text { Sum of } \\
\text { Squares }\end{array}$ & Df & Mean Square & $\mathrm{F}$ & Sig. \\
\hline \multirow[t]{3}{*}{1} & Regression & 18359,509 & 7 & 2622,787 & 6,009 &, $000^{\mathrm{b}}$ \\
\hline & Residual & 64596,466 & 148 & 436,463 & & \\
\hline & Total & 82955,974 & 155 & & & \\
\hline
\end{tabular}

a. Dependent Variable: LAGT

b. Predictors: (Constant), SIZE, LV, KI, KK, OA, ERP, ROA

Sumber: Hasil Pengujian Data, 2020 
Berdasarkan hasil pengolahan SPSS pada tabel 4.10 diatas, dapat dilihat bahwa $\mathrm{F}_{\text {hitung }}$ adalah sebesar 6,009. Nilai $F_{\text {tabel }}$ pada $\alpha=0,05$ adalah kombinasi dari $\mathrm{k}=7$ dan df: $\mathrm{n}-\mathrm{k}=156-7=148$ sebesar 2,10. Hal ini menunjukkan nilai $F_{\text {hitung }} 6,009>F_{\text {tabel }} 2,10$ sedangkan nilai signifikansi sebesar $0,000<0,05$. Maka dapat disimpulkan bahwa enterprise resource planning, konsentrasi kepemilikan, komisaris independen, leverage, profitabilitas, opini audit dan ukuran perusahaan dapat berpengaruh secara simultan (bersama - sama) terhadap variabel dependen.

\section{Uji Parsial (Uji t)}

Uji parsial ( $\mathrm{t}$ ) digunakan untuk menguji sampai sejauh mana variabel independen secara individu dalam menerangkan variasi variabel dependen (Ghozali, 2016). Kriteria yang digunakan dalam mengambil keputusan yaitu :

1. $\mathrm{t}$ hitung $>\mathrm{t}$ tabel pada $\alpha=5 \%$ dan nilai probabilitas $<$ level of significant sebesar 0,05 , maka variable $\mathrm{X}$ berpengaruh terhadap variable $\mathrm{Y}$.

2. thitung $<\mathrm{t}$ tabel pada $\alpha=5 \%$ dan nilai probabilitas $>$ level of significant sebesar 0,05 , maka variable $\mathrm{X}$ tidak berpengaruh terhadap variable $\mathrm{Y}$.

Hasil pengujian uji signifikansi parsial (uji T) dalam penelitian ini ditunjukkan dalam tabel di bawah:

Tabel 4.11 Hasil Uji t

coefficient $^{\mathrm{a}}$

\begin{tabular}{|c|c|c|c|c|c|c|}
\hline \multirow{2}{*}{\multicolumn{2}{|c|}{ Model }} & \multicolumn{2}{|c|}{$\begin{array}{l}\text { Unstandardized } \\
\text { Coefficients }\end{array}$} & \multirow{2}{*}{$\begin{array}{c}\text { Standardized } \\
\text { Coefficients } \\
\text { Beta }\end{array}$} & \multirow[b]{2}{*}{$\mathrm{T}$} & \multirow{2}{*}{ Sig. } \\
\hline & & B & Std. Error & & & \\
\hline \multirow[t]{8}{*}{1} & (Constant) & 156,761 & 29,329 & & 5,345 &, 000 \\
\hline & ERPit & $-12,520$ & 3,766 &,- 271 & $-3,324$ & ,001 \\
\hline & KKit & 7,242 & 5,714 & ,095 & 1,268 & ,207 \\
\hline & KIit & 8,253 & 18,859 & ,032 & ,438 & ,662 \\
\hline & Lvit & $-42,663$ & 10,862 &,- 327 & $-3,928$ &, 000 \\
\hline & ROAit & $-119,946$ & 42,583 &,- 242 & $-2,817$ &, 006 \\
\hline & OAit & $-16,368$ & 9,851 &,- 125 & $-1,662$ & ,099 \\
\hline & SIZEit &,- 953 & 1,324 &,- 059 &,- 719 & ,473 \\
\hline
\end{tabular}

a. Dependent Variable: LAGTit

i

Sumber: Hasil Pengujian Data, 2020

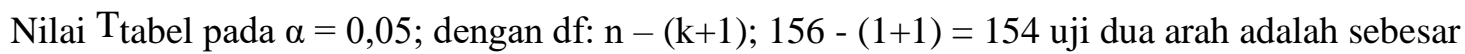
1,975 maka dapat dijelaskan sebagai berikut :

1. Berdasarkan uji hipotesis $t$ menunjukkan nilai $\mathrm{T}_{\text {hitung }}<$ nilai $\mathrm{T}_{\text {tabel }}(-3,324<1,975)$ dan nilai signifikansi $0,001<0,05$. Hal ini menunjukkan bahwa ERPit berpengaruh secara signifikan terhadap relevansi informasi akuntansi.

2. Hasil uji t pada variabel KKit menghasilkan nilai $T_{\text {hitung }}<$ nilai $T_{\text {tabel }}(1,268<1,975)$ dan nilai signifikansi 0,207>0,05, yang berarti variabel KKit tidak berpengaruh terhadap relevansi informasi akuntansi.

3. Hasil uji t pada variabel Klit menghasilkan nilai $\mathrm{T}_{\text {hitung }}<$ nilai $\mathrm{T}_{\text {tabel }}(0,438<1,975)$ dan nilai signifikansi $0,075>0,05$, yang berarti variabel Klit tidak berpengaruh terhadap relevansi informasi akuntansi.

4. Hasil uji $t$ pada variabel LVit menghasilkan nilai $\mathrm{T}_{\text {hitung }}<$ nilai $\mathrm{T}_{\text {tabel }}(-3,928<1,975)$ dan nilai signifikansi $0,000<0,05$, yang berarti variabel LVit berpengaruh dan signifikan terhadap relevansi informasi akuntansi.

5. Hasil uji t pada variabel ROAit menghasilkan nilai $\mathrm{T}_{\text {hitung }}<$ nilai $\mathrm{T}_{\text {tabel }}(-, 817<1,975)$ dan nilai signifikansi $0,006<0,05$, yang berarti variabel ROAit berpengaruh dan signifikan terhadap relevansi informasi akuntansi.

6. Hasil uji t pada variabel OAit menghasilkan nilai $\mathrm{T}_{\text {hitung }}<$ nilai $\mathrm{T}_{\text {tabel }}(-1,662<1,975)$ dan nilai signifikansi 0,099>0,05, yang berarti variabel OAit tidak berpengaruh terhadap relevansi 
informasi akuntansi.

7. Hasil uji t pada variabel SIZEit menghasilkan nilai $T_{\text {hitung }}<$ nilai $T_{\text {tabel }}(-0,719<1,975)$ dan nilai signifikansi $0,473>0,05$, yang berarti variabel SIZEit tidak berpengaruh terhadap relevansi informasi akuntansi.

\section{Koefisien Determinasi $\left(\mathbf{R}^{2}\right)$}

Koefisien determinasi $\left(\mathrm{R}^{2}\right)$ pada intinya mengukur seberapa jauh kemampuan model dalam menerangkan variabel dependen. Nilai $R^{2}$ yang kecil berarti kemampuan variabel independen dalam menjelaskan variabel dependen amat terbatas. Nilai yang mendekati satu berarti variabel-variabel independen memberikan hampir semua informasi yang dibutuhkan untuk memprediksi variasi variabel dependen (Ghozali, 2016). Hasil yang diperoleh dari uji koefisien determinasi $(R 2)$ dapat dilihat pada tabel berikut ini:

Tabel 4.12 Hasil Uji Koefisien Determinasi

\begin{tabular}{|c|c|c|c|c|}
\hline \multicolumn{5}{|c|}{ Model Summary ${ }^{\text {b }}$} \\
\hline Model & $\mathrm{R}$ & R Square & Adjusted R Square & $\begin{array}{l}\text { Std. Error of the } \\
\text { Estimate }\end{array}$ \\
\hline 1 &, $736^{\mathrm{a}}$ & ,542 &, 513 & 13,59720 \\
\hline
\end{tabular}

a. Predictors: (Constant), SIZE, LV, KI, OA, KK, ERP, ROA

b. Dependent Variable: LAGT

Sumber: Hasil Pengujian Data, 2020

Berdasarkan tabel 4.12 diketahui bahwa Nilai $R$ Square sebesar 0,513 atau 51,3\%. Hal ini menunjukkan bahwa variabel enterprise resource planning, konsentrasi kepemilikan, komisaris independen, leverage, roa, opini audit, dan ukuran perusahaan dapat menjelaskan variabel relevansi inormasi akuntansi sebesar 51,3\%, sedangkan sisanya sebesar $48,7 \%$ dijelaskan oleh variabel lain diluar model penelitian ini.

\section{Pembahasan}

Berdasarkan dari hasil pengujian SPSS menunjukan bahwa nilai Fhitung adalah sebesar 6,009. Nilai Ftabel pada $\alpha=0,05$ adalah kombinasi dari $\mathrm{k}=7$ dan df: $\mathrm{n}-\mathrm{k}=156-7=148$ sebesar 2,10. Hal ini menunjukkan nilai Fhitung 6,009 > Ftabel 2,10 sedangkan nilai signifikansi sebesar 0,000 < 0,05 . Maka dapat disimpulkan bahwa variabel enterprise resource planning, konsentrasi kepemilikan, komisaris independen, leverage, profitabilitas, opini audit dan ukuran perusahaan dapat berpengaruh secara simultan (bersama - sama) terhadap variabel dependen, yaitu relevansi informasi akuntansi.

Berdasarkan uji hipotesis $t$ untuk ERP menunjukkan nilai Thitung< nilai Ttabel $(-3,324<1,975)$ dan nilai signifikansi $0,001<0,05$. Hal ini menunjukkan $\mathrm{H} 1$ diterima sehingga dapat disimpulkan bahwa ERPit berpengaruh negatif signifikan terhadap relevansi informasi akuntansi.

Pengunaan ERP pada perusahaan dapat membantu mempermudah pengerjaan laporan keuangan serta dapat mempersingkat waktu pengerjaannya. Tetntu saja hal ini membuat perusahaan- perusahaan di Indonesia menggunakan sistem ERP untuk mempersingkat waktu pemprosesan laporan keuangan sehingga penyampaian laporan keuangan ke pengguna dapat tepat waktu. Penggunaan sistem enterprise resource planning (ERP) di Indonesia belum banyak dikarenakan biaya yang harus dikeluarkan oleh perusahaan untuk mengimplementasikannya tidak sedikit, serta untuk merubah proses bisni dari sebeleum menggunakan ERP sampai dapat mengimplementasikan ERP secara penuh juga memakan waktu yang cukup lama. Hal ini yang menjadi beberapa alasan kenapa masih banyak perusahaan yang belum menggunakan sistem ERP padahal secara umum sistem ERP dapat membantu proses bisnis menjadi lebih efisien. Hasil penelitian ini sesuai dengan penelitian $\mathrm{Ou}$, et all (2018) yang menyatakan bahwa sistem ERP berpengaruh signifikan terhadap relevansi informasi akuntansi. 
Penelitian ini juga memasukan beberapa variabel kontrol yaitu konsentrasi kepemilikan (KK), komisaris independen (KI), leverage (LV), profitabilitas (ROA), opini audit (OA), dan ukuran perusahaan (SIZE) dengan tujuan untuk mengontrol pengaruh enterprise resource planning (ERP) terhadap relevansi informasi akuntansi sehingga hasil analisis lebih menjelaskan pengaruh yang optimal karena variabel-variabel lain yang juga dapat mempengaruhi variabel dependen.

Berdasarkan tabel 4.11 hasil uji t pada variabel konsentrasi kepemilikan (KK) menghasilkan nilai Thitung < nilai Ttabel $(1,268<1,975)$ dan nilai signifikansi $0,207>0,05$, yang berarti variabel KK tidak berpengaruh terhadap relevansi informasi akuntansi. Hasil penelitan ini sesuai dengan hasil penelitian Rohmatullaily (2019). Adanya kepemilikan saham yang terkonsentrasi atau tersebar dalam perusahaan tidak menunjukan adanya kepentingan antar pemilik saham sehingga hal ini memungkinkan terjadinya motif memperkaya diri sendiri, namun manajemen akan tetap menjagakredibilitas laporan keuangan yang dihasilkannya karena mereka tidak ingin nantinya akan kehilangan rasa kepercayaan investor untuk menanamkan investasi pada perusahaannya.

Berdasarkan tabel 4.11 hasil uji t pada variabel komisais independen (KI) menghasilkan nilai Thitung < nilai Ttabel $(0,438<1,975)$ dan nilai signifikansi $0,075>0,05$, yang berarti variabel KI tidak berpengaruh terhadap relevansi informasi akuntansi. Hasil penelitian ini sesuai dengan penelitian Liyanto \& Anam (2018) .komisaris independen tidak berpengaruh terhadal relevansi informasi akuntansi disebabkan karena keberadaan dan pengangkatan komisaris independen dilakukan hanya untuk memenuhi regulasi dan monitoring yang dijalankan komisaris independen kurang optimal atau belum efektif sebagai alat untuk memonitor manajemen.

Berdasarkan tabel 4.11 hasil uji t pada variabel leverage (LV) menghasilkan nilai Thitung $<$ nilai Ttabel $(-3,928<1,975)$ dan nilai signifikansi $0,000<0,05$, yang berarti variabel LV berpengaruh negatif dan signifikan terhadap relevansi informasi akuntansi. Hasil penelitian ini sesuai dengan penelitian Yulinda (2016). Leverage berpengaruh signifikan terhadap relevansi informasi akuntansi dikarenakan apabila tingkat leverage perusahan semakin tinggi maka akan meningkatkan resiko investor sehingga investor menuntut perusahaan untuk dapat memperoleh keuntungan yang besar. Hal ini mengakibatkan manajemen melakukan manipulasi laporan keuangan yang tentu saja memakan waktu yang cukup lama dan berakibat juga pada terlambatnya perusahaan menyampaikan laporan keuangannya.

Berdasarkan tabel 4.11 hasil uji t pada variabel profitabilitas (ROA) menghasilkan nilai Thitung< nilai Ttabel $(-, 817<1,975)$ dan nilai signifikansi $0,006<0,05$, yang berarti variabel ROA berpengaruh negatif dan signifikan terhadap relevansi informasi akuntansi. Hasil penelitian ini searah dengan penelitian Alamsyah (2017). Proitabilitas berpengaruh negatif dan signifikan terhadap rrelevansi inormasi akuntansi dikarenakan jika laporan keuangan perusahaan menampilkan nilai laba yang meningkat setiap tahun pengamatan makan investor cenderung untuk menanamkan modalnya kepada perusahaan tersebut sehingga hal ini dapat dijadikan motif manajemen untuk memanipulasi laporan keuangan apabila laba yang dihasilkan mengalami penurunan.

Berdasarkan tabel 4.11 Hasil uji t pada variabel opini audit OA menghasilkan nilai Thitung < nilai Ttabel $(-1,662<1,975)$ dan nilai signifikansi $0,099>0,05$, yang berarti variabel OA tidak berpengaruh terhadap relevansi informasi akuntansi. Hasil penelitian ini searah dengan penelitian Hantoto (2016). Opini audit pada penelitian ini tidak berpengaruh terhadap relevansi informasi akuntansi bisa disebabkan karena adanya peraturan BAPEPAM Nomor X.K.2 yang mengharuskan perusahaan untuk melaporkan laporan keuangnnya selambat-lambatnya pada akhir bulan ketiga setelah tanggal laporan keuangan tahunan, sehingga memaksa manajemen untuk tetap melaporkan laporan keuangannya meski menerima opini audit selaian wajat tanpa pengecualian.

Berdasarkan tabel 4.11 asil uji t pada variabel ukuran perusahaan (SIZE) menghasilkan nilai Thitung $<$ nilai Ttabel $(-0,719<1,975)$ dan nilai signifikansi $0,473>0,05$, yang berarti variabel SIZE tidak berpengaruh terhadap relevansi informasi akuntansi.hasil penelitian ini sesuai dengan penelitian $\mathrm{Ou}$, et all (2018). Meski perusahaan memiiki aset yang besar serta memnggunakan sistem yang canggih, namun perusahaan tersebut juga memiliki lingkungan yang kompleks, sehingga juga 
terkadang mereka mengalami kesulitan dalam menjalankan bisnisnya dan juga memerlukan waktu yang lebih lama dalam mengintegrasikan data. Sedangkan pada perusahaan yang lebih kecil akan sebaliknya.

\section{Kesimpulan}

Berdasarkan hasil analisis penelitian dapat dibuktikan bahwa enterprise resouce planning (ERP) berpengaruh terhadap relevansi informasi akuntansi. Hasil ini menunjukkan bahwa ketika perusahaan menggunakan sistem enterprise resource planning (ERP) maka sistem tersebut memberikan dampak yang signifikan terhadap informasi akuntansi yang dihasilkan dengan meningkatnya relevansi dari informasi akuntansi perusahaan tersebut.

Sementara untuk variabel kontrol pada uji $\mathrm{T}$ menunjukkan bahwa hanya leverage (LV) dan profitabilitas (ROA) yang menunjukkan nilai signifikan dan berpengaruh terhadap relevansi informasi akuntansi. Sedangkan untuk variabel kontrol konsentrasi kepemilikan (KK), komisaris independen (KI), opini audit (OA) dan ukuran perusahaan (SIZE) tidak terbukti dan tidak berpengaruh secara signifikan terhadap relevansi informasi akuntansi.

Penggunaan sistem enterprise resource planning (ERP) di Indonesia belum banyak di karenakan biaya yang harus dikeluarkan oleh perusahaan untuk mengimplementasikannya tidak sedikit, serta untuk merubah proses bisni dari sebelum menggunakan ERP sampai dapat mengimplementasikan ERP secara penuh juga memakan waktu yang cukup lama. Hal ini yang menjadi beberapa alasan kenapa masih banyak perusahaan yang belum menggunakan sistem ERP padahal secara umum sistem ERP dapat membantu proses bisnis menjadi lebih efisien.

\section{Referensi}

Ghozali, Imam. 2013. "Aplikasi Analisis Multivariate dengan Program SPSS. Semarang: Badan Penerbitan Universitas Diponegoro.

Irfani, M. H. (2015). Erp (Enterprise Resource Planning) Dan Aspek-Aspek Penting Dalam Penerapannya. INFORMATIKA, 04, 105-114.

Sugiyono. 2017. Metode penelitian Kuantitatif,Kualitati, dan R\&D.Bandung: Alfabeta,CV Susanto, P. D. A. (2017). Sistem Informasi Manajemen: Konsep dan Pengembangan Secara Terpadu.

Alamsyah, S.(2017). Pengaruh Profitabilitas Terhadap Nilai Perusahaan, Relevansi Nilai Informasi Akuntansi, Keputusan Investasi, Kebijakan Dividen Sebagai Variabel Intervening (Studi Empiris Pada Perusahaan Indeks Kompas 100 Periode 2010-2013). Jurnal Ilmiah Fakultas Ekonomi dan Bisnis Universtas Muhammadiyah Tanggerang. Vol 1(1), 136-161.

Albitar, K. (2015). Firm Characteristics, Governance Attributes and Corporate Voluntary Disclosure: A Study of Jordanian Listed Companies. International Business Research, 8(3), 1-10.

Alvin. (2018). Relevansi Nilai Informasi Akuntansi Sebelum dan Sesudah Penerapan XBRL di Bursa Efek Indonesia.

Ballesta, J. P. S., \& Meca, E. G. (2005). "Audit qualifications and corporate governance in Spanish listed firms". Managerial Auditing Journal, 20(7), 725-738.

Brazel, J. F. (2008). The Effect of ERP System Implementations on the Management of Earnings and Earnings Release Dates. 22(2), 1-21.

Budiyanto, Sarwono dan Elma Mancar Aditya. 2015. "Faktor-Faktor Yang Mempengaruhi Ketepatan Waktu Laporan Keuangan (Studi Empiris Perusahaan Food and Beverages periode 20102012)”. Fokus Ekonomi Vol. 10 No. 1 : 77-78. 
Budiartha, I. K. (2016). Informasi Dan Perceived Usefulness Pada Kepuasan Pengguna Akhir Software Akuntansi ( Studi Empiris Pada Hotel Berbintang Di Provinsi Bali ). Magister Akuntansi Fakultas Ekonomi dan Bisnis , Universitas Udayana ( Unud ), Bali Akuntansi merupakan suatu sist. E-Jurnal Ekonomi Dan Bisnis Universitas Udayana, 1, 115-142.

DeLone, W. H., \& McLean, E. R. (1992). Information systems success: The quest for the dependent variable. Information Systems Research. https://doi.org/10.1287/isre.3.1.60

Dewi, I. P. (2016). Pengaruh Implementasi Enterprise Resource Planning (Erp) Dan Kompetensi Pengguna Terhadap Kualitas Informasi Akuntansi. Jurnal Sains Manajemen \& Akuntansi, 08, $11-24$.

Galy, E., \& Sauceda, M. J. (2014). Post-implementation practices of ERP systems and their relationship to financial performance. Information and Management, 51(3), 310-319.

Ghozali, Imam. 2013. "Aplikasi Analisis Multivariate dengan Program SPSS. Semarang: Badan Penerbitan Universitas Diponegoro.

Indasari, A., Yuliandari, W.S., \& Triyanto, D.N. (2016). Pengaruh Komisaris Independen,

Komite Audit, Dan Financial Distress Terhadap Integritas Laporan Keuanga. Jurnal Ilmiah Akuntansi Fakultas Ekonomi Universitas Volume XX, No. 01: 117-133.

Indrayani, M. (2017). Pengaruh Penerapan Sistem Informasi Akuntansi Terhadap Kualitas Output Sistem Informasi Akuntansi dan Sistem Pengendalian Internal Pada Perusahaan BUMN Pengguna Sistem Enterprise Resource Planning (ERP) di Kota Lhokseumawe. 10, 119-138.

Irfani, M. H. (2015). Erp (Enterprise Resource Planning) Dan Aspek-Aspek Penting Dalam Penerapannya. INFORMATIKA, 04, 105-114.

Jensen, C., \& Meckling, H. (1976). Theory Of The Firm : Managerial Behavior, Agency Costs And Ownership Structure I . Introduction and summary In this paper WC draw on recent progress in the theory of ( 1 ) property rights, firm . In addition to tying together elements of the theory of e. $3,305-360$.

Keputusan Ketua Badan Pengawas Pasar Modal Dan Lembaga Keuangan Nomor: Kep- 643/B1/2012 Tentang Pembentukan Dan Pedoman Pelaksanaan Kerja Komite Audit

Kuntum, C. (2019). Effect Of Implementation Of Enterprise Resource Planning System On Quality Of Accounting Information. 3, 15-20.

Kwong, L. C. (2010). The value relevance of financial reporting in Malaysia: Evidence from three different financial reporting periods. International Journal of Business and Accountancy.

Liyanto,L.W \& Anam,H. (2018). Proporsi Komisaris Independen, Dewan Komisaris, Kompetensi Komite Audit, Frekuensi Rapat Komite Audit Terhadap Konservatisme Akuntansi. Jurnal Universitas Balikpapan, E-ISSN: 2503-4790,130-149

Nuryanti, D., \& Suprantiningrum, R. (2016). Analisis Dan Perancangan Sistem Informasi Akuntansi Penjualan, Piutang Dan Penerimaan Kas (Studi Kasus pada UD.Praktis di Magetan). Jurnal Ilmiah UNTAG Semarang, 5(2), 100-112.

Ou, P., Zhao, H., \& Zhou, Z. (2018). Does the implementation of erp improve the quality of accounting information? Evidence from chinese a-share listed manufacturing firms. Journal of Applied Business Research, 34(1), 43-54. 
Rahayu, R. T. (2018). Pengaruh Implementasi Enterprise Resource Planning (Erp) Terhadap Kualitas Informasi Akuntansi Dengan Kompetensi Personal Pengolahan Data Sebagai Variabel Moderating.

Rahman, F. (2018). Evaluasi Penerapan Enterprise Resources Planning (Erp) Terhadap Penyajian Laporan Keuangan (Studi Kasus Di Pt. Surya Citra Televisi). KREATIF: Jurnal Ilmiah Prodi Manajemen Universitas Pamulang, 6(3), 109.

Rohmatullaily, N. (2019). Pengaruh Konsentrasi Kepemilikan, Transaksi Dengan Pihak Berelasi Dan Manajemen Laba Terhadap Daya Informasi Akuntansi. Jurnal Jurusan Akuntansi Prodi Ekonomi Univesitas Negeri Surabaya.

Sudirman. (2013). Pengaruh Implementasi Sistem Erp (Enterprise Resource Planning) Terhadap Kualitas Informasi (Studi Kasus Pada PT. Jasa Marga (Persero) Tbk. Cabang Purbaleunyi).

Kurniawati, M., Gunarta, K., \& Baihaqi, I. (2015). Dampak Implementasi Enterprise Resource Planning (Erp) Pada Kinerja Keuangan: Pendekatan Resources Based View. Jurnal Manajemen Teknologi, 1-9. Retrieved from http://mmt.its.ac.id/download/SEMNAS/SEMNAS XXIII/MI/12. 